Porenger por:

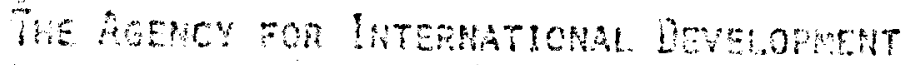

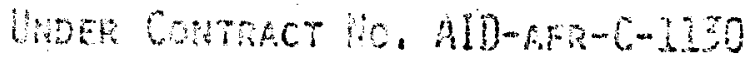

4.0 .794

IRRGGTES AGROCULTUE IN AFGHAMSTAN

DECEMBER 1978

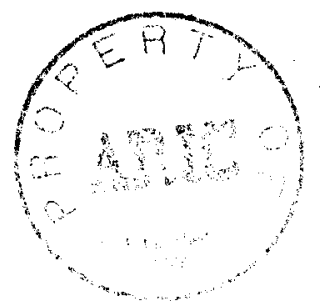


EXPERIENCE, INCORPORATED Counsel to Decision Makers

EXPERIENCE* - Agriculture Agribesines

IT26 K STREET N.W. SUTTE 312

WASH IINTTON, D.C. 20006 U.S.A.

$1202: 080-3964$

December 1978

Mr. Fred Marti

NE/TECH/AD

Agency for International Develupment

Wasington DC 20523

Subject: Contract AID/afr-C-1130, Work Order No.94.

Dear Mr. Marti:

We are pleased to transmit to you copies of our report titled Irrigated Agriculture In Afghanistan. Which reflects the analyses called for in the subject work order. This report identifies the principal problems and constraints affecting irrigated agriculture in Afghanistan, describes possible solutions to these probler areas, and presents groupings of these solutions in 'technicai packages' we believe suitable for incorporation into future projest Identification Documents. As such, the recommendations in section II. are of a broad nature and nave nationwide relevancy.

We would like to add to the Acknowledgements expressed in this keport our thanks to $A I D / W$ and USAID/Afghinistan staff who measurably assisted us in this undertakiny.

Siricerely,

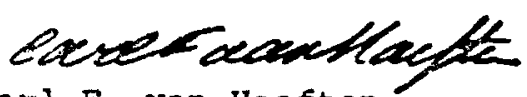

Carl F. van Haeften

Project Aaministrator

$\operatorname{lp}$

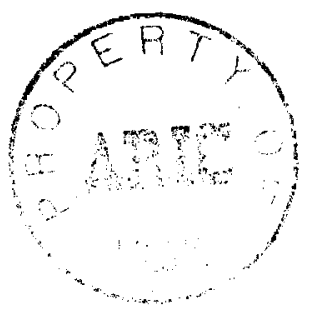




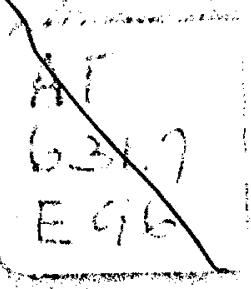

THE AgEHCY FOR InTERNATICNAL DEVELOPMEAT UNDER CONTRACT MO. AD-AFR-C-1130

H.O. 94

\title{
IRRIGATED AGRICULTURE IN AFGHANISTAN
}

\author{
DECEMBER 1978
}

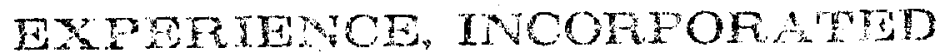
MINNEAPOISI MINNESOTA 55402 
I. Letter of Transmittal

II. Recommendations

III. Introduction to Report

IV. Problems and constraints

v. Possible Alternative Solutions

VI. Potential impact of Technical Packages

viI. Additional Unevaluated Constraint.j

\section{ANNEXES}

Annex 1 Use of Ground Water and Recharge to Ir.crease Agricultural Production

Annex la The Potential Impact of "Technical Packages" in Ground water Exploration and Inventory, Development and Recharge

Annex 2 The Role of Soils in Land Development to Increase Agricultural Eroduction

Annex 3 National Water Resources Commission

Annex 4 Methodology Used

Annex 5 Discussion Notes on the Irrigation Survey 


\section{RECOMAENDATICNS}

1. Investigate ground water potential of both deep and shallow wells.

2. Rehabilitats the small scale irrigation systems for improving water contrcl throughout the complete system.

3. Introduce improved crop hisbandry based on crop water use efficiencies and water management practices on the farm.

4. Initiate land improvement work, including on-farm infrastructure, to improve on-farm water management.

5. Begin water and related land resource inventories to provide data for planning and designing irrigation projects. 


\section{INTRODUCTION TU THE REPORT}

A. Scope and Authorization.

This Study, 'mplemented jointly by a team of engineering and agricultural specialists from Experience, Incorporated (the Contractor), and a group of technical specialists from the Agency for International Development's Mission to Afghanistan (USAL/Afgh.'m. an), has comprised an Intensive revilew, during a two-month rerlod, of past and present developments ix Irrigated agrtculture within the Democratic Republic of Afghanistan (DRA). The Study has measurably benefited from review by, discussions with, ard cuntributions from DKA ofiricials of iWinistries acd Departmomis concerned with such irrigated agricultural developments. DRA officials Jiso joined members of the Contractor's team and USAID tecknicians in visiting and inspecting irrigation systems in many parts of Afghanistan.

The participation of the Contractor's team was authorized by Contract No. AID/afr-C-1130, dated 29 Septembei 1978. (Work Order No. 94)

B. Objective of the Study

The objective of the Study, as stated in Article II of the Work Order is to iderifify and recommerd for further investigation new procedures and tochnologies that could lead to an increase in the arailability and the efficient use of water for agriculturas production in ways approcriate to we 
poorer farmers.

C. Purpose of the Report

This Report summarizes the findings of the reviews and invest1Extinas made during the Study. It has been divided into the following Sections:

- Determination of problems and constraints currently hampering or capable of imposing future limitations on the development of irrigated agriculture;

- Description of possible alternative solutions responsive to the aforementioned problems and comstraints;

- Formulation of 'technical packages" through the selective cominination of prossibie solutions;

- Identification for future reference of certain unevaluated constrainte which were outside the purview of the present Report.

D. Methodology

Dotails of the methodology employed in this assessment of irrigated agriculiture in Afghanistan are presented in Annex 4.

E. Acknowledgements

The Contractor's efforts in tive implementation of this Sturty and the preparation of the Report were substantially halped and beneited by the considerable assistance, support, and factalal inputs from USADD, specifl- 
cally from the offlces of the Depity Director, Agriculture, and Program.

Further help, cf vory significant value, was proplded by DRA of-

ficials and staff of Ministrles and other departments and agencles concerned with Irrigated agriculture in Afghanistan. The gratitude of the Contractor is particularly extended to the following for their contributions to this Study:

Ministry of Planning

Mr. Fateh Mohamad Taris

- Deputy Minister

Dr. Usman Akram

- Geveral Director, Agriculture and Irrigation

Mir. Jafar Kazem

- President, Foreign Relations Department.

Mrnistry of Agriculture and Land Reform

Mr. Abdul Ahad Sarsam

- Deputy Mirister

Mr. Mohamed Hasan Paiman

- Presidert of Extension

Mir. Jan inohamed

- Presidedi Evaluation, Exien-

Mr. Feda Mohamed Hashimi Stun Dopatment

- Staff Memuer, Extension Department

Ministry of Water and Powrer Mr. Nassim Azimi.

- President, Planning

Mr. Mohamed Ali

- Staff Member. Planning

Mr. Farouq

- Stalf Member, Planning

Kural Development Department

Mr. Sulemarizai

- President

Mr. Hokmatullab

- Vice President

Mr. Sayed Altar

- General Director, Irrigation

Agriculture Develspment Bank

Mr. Abdul Tawab Asefi

Mr. Sayed Abcul Rabman Hashimi - General Director, Credit 


\section{N. PROBLEMS AND CONSTRAINTS}

\section{A. Introduction}

The identiffcation of major problems and constraints inhibiting the development of irrigated agriculture was achieved through three stages:

A farm irodel irrigation supply system was synthesized in a step-by-step process from the indlvidual farmer's plot, tlirough the several components of the system, to the ultimate source of the irrigation water supply. From this the key variables were identifled, and through consicieration of these dependent variables and the rpspective causal relationshlps involved, problem areas and constraints frithin tive basic supply system were highlighted.

An effecitve demand structure with corresponding dependent variables to complement the abor.s supply system was then establishod. This in turn led to a preliminary listing of problem areas and constraints for each of the key variables in the effective demand structurie.

Through ro-examination of the various problerns and constraints, cross-critiguing, and Extensive discussion among the Contractor-USADDRA participants, the major variables surfaced and were placed $1: 2$ order of priority, lesser variables were relegated to minor posttions or elimIrated, and the principal problem areas and constraints were established arcound which possible solutions and "technical packages" were later 
developed.

A more detalled ciescripticn of the development of the three stages foilows.

\section{Elements of a Representative Irrigated Agricultural (supply) System.}

The diagram in Figure I-1 comprebensively lists in matrix form the principal components of a representative Irrigated agricultural system.

The catchment ares is the source from which irrigation water is derived. Human intervention in the form of diversions, elther from surface or from groundwater sources, captures a supply of water from the resource area. This in turn flows through a network or partial network of conveyance facllities to farmers' fields. Optimal withdrawals from the resource area together with the performance characteristics of tho convegance system are major determinants in suppiying acequate deliverieg of water to farmers' flelds.

A favorable environment for growing plants usually required, in addition to appropriate water or molsture avallabllity, some kind of drainage rolief system for the disposal of excess water. This olsviates soil saturation and thus ensures the accessibllity of aerobic bacteria anc plant rcots to sufficlent amounts of oxygen.

Appropriate farm infrastructure, inuiuding well-graded flelds permiting a uniform application of water; efilclent inter-fleld distribution 


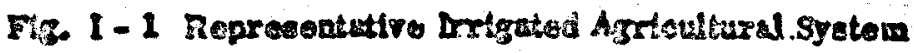

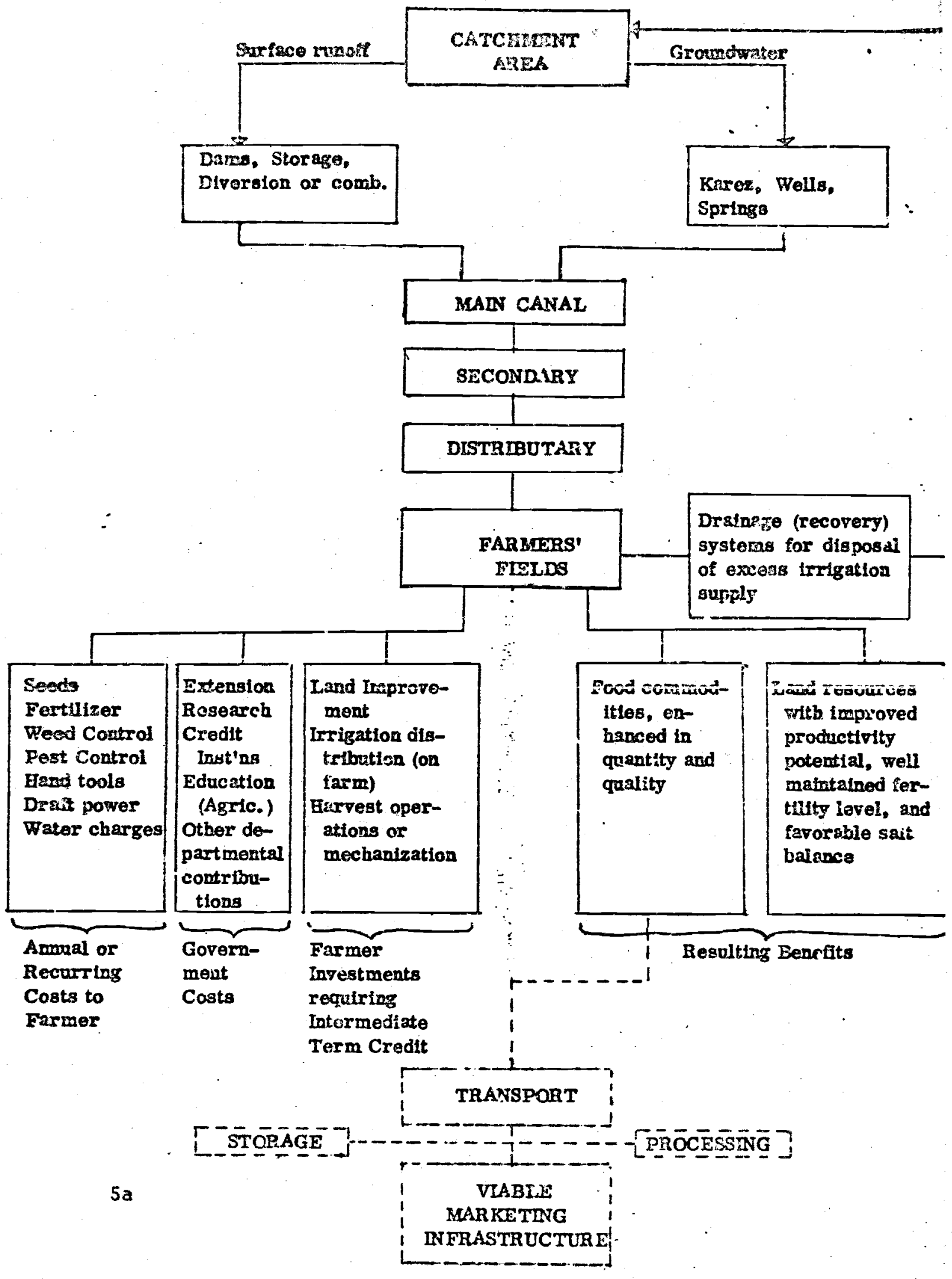


systems; well-developed soll proflles; and perbups some mochanization. to perratt more timely farming practices to bo applied, requires tr ?estment by the farmer. To effect this, idtormetilite on izig-term crodit Is usually needed.

The farmer also .eeds technical assistance in establishing approp riate inirastructure on the farm. This frequently takes the form of adFice and counsel on more modern agrtcultural practices, especially water management, in order to obtain improved yield levels. Certain institutiojal needs, which are normally supplied at government cost, are concerned with his access to credit, agricultural schools, and research stations, as well as other governmental service organizations.

Farmers aro also faced with costs which are anmill, recurring, or which vary according to the cropping cycle. These comprise good quality seods; fertilizer ard other agricultural chemicals; tools; maintenance of power, whether machine fuel or feed for animals; and in most countries, water charges. Small-scale farmers usually require short-term production credit for amortizing these costs.

Finally, local supporting enterpirises are nsecled to handle the harvested crop. Basic eiements of the crop-handling support system are shown as transport, storage, processing (where required), and marketing.

2. Anajysis of User-demand Relationships. 
The starting point for this analysis was arbitrarily takin as the Lodividual farmer's plot, and the key oariables, as well as the respective factors which contriluted to them, were then devoloped: flrst for the supply system, and then for the complementary effective demand. Foilowing taterfacing and discussion with DRA officials, the supply and demand syatems were refined and the most significant variables arranged in order of importance. Table I-1 shows the components of these two on-farm irrigation systems and indicates the caisal relationships that are considered to exist and to affect Irrigated agricultural practicss in Afghanistan. These conditions are described in the following paragraphs of this Section, each keyed to the respective kev variable:

\section{B. SIPPIY SYSTEM PROBLEMS}

1. Resources

There is insufficient knowledge concerning the extent and quality of the country's water resources. In the case of streamflow, for example, the number of gaging stations is about 80 percent of the total recommended by the U.S. Geological Survey about 12 years ago; data quality, however, is . not commensurate, as there are considerable data that are classiffi:- as only fair to poor; and there have apparently tan a number of cases where shifting controls have affected rating curves. Moreover, reduced budget allocations have been respensible for shortfalls in actual departmen- 


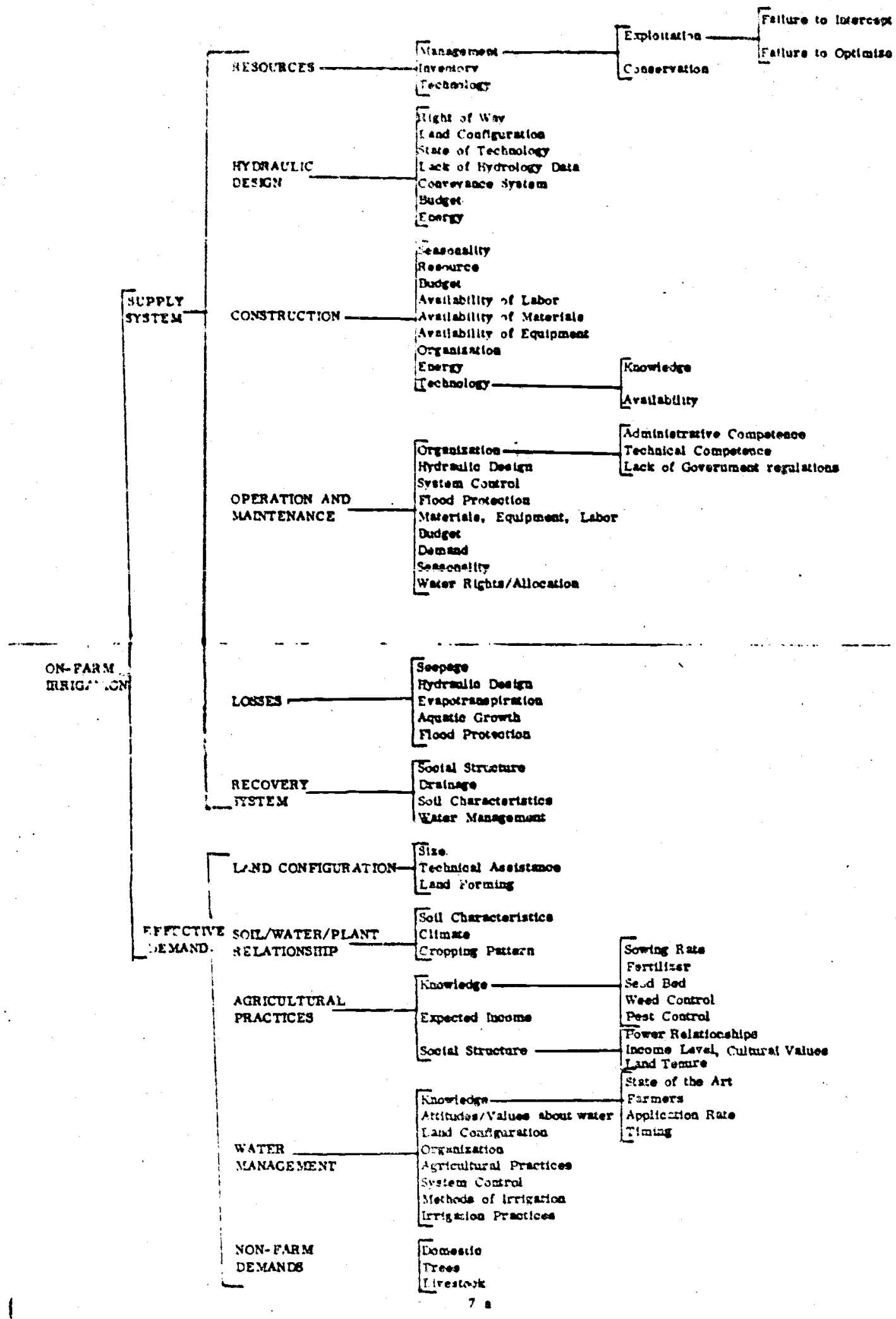


tul requirement.

Similariy, groundwater Inventory has been scanty, loculzed and Generaliy Inadequate for purposes of complete resource ovaluation. No long-term records are avallable, draudown-recovery data exdst for only a few areas, and no evidence was furnished of a regular program for hydrogeological study. Exploitation of these water rescurces has been permitted to proceed without adequate planning, reflecting further lack of knowledge of the resource itself. No significant attempt at conservation has yet been undertaken, although an Interest has been expressed in groundwater recharge. The technology to optimize the usage of surtace and groundwaters exists outside Afghanistan, and is probably loown to a IImited extent at Mlistry level or equivalent, but research and investigation leading to practical applications appear to be at a rudimentary stage, at best.

Adequate soll productivity investigations, including determinations of soll fertility, have probably never been mado in Afghanistan, at least to any area-wide extent, and consequently land capability classification does not exist. A llmited and very generallzed soil reconnaissance survey was made by a UN group in 1963. Soils laboratories visited were deflsient in experienced staff and modern equipment, and appeared to be more concerned with water analysis than solls. There was no evidence of a national solls policy or of any cotuntry-wide solls investigation programs. 
Records appeared to be incomplete and unrellable, due again, perbaps, to Inadequate or inexperienced staff.

2. Mydraulle Deslgn

As related to on-farm Irrigation supply systems in Afghanlstan, bydraulic design suffers initial:y from a lack of relevant bydrologic data, of which farmers' groups have only an empirical awareness. Additionally, coaveyance systems are less subject to acceptable hydraulc design than they are to land configurations and right-of-way limitations. The degree of technology resorted to is often primitive, for assistance to farmer groups in remote areas from such government agencies as have sufficient technical ability is limited and often non-existent.

Additional constraints on the design of the supply system are presented by limited enurgy and buogetary resources: a small pumping station that would obviate an overiy-long conveyance system could well be precluded because of lack of power and fuel, as well as by the meager funds avallable for the purchase of the equipment itself.

\section{Construction}

Particularly where the building of a sizable river diversion structure, dam, or weir is concerned, construction operations of supply systems are subject to the magnitude of streamnlow that maust be diverted during such 
construction. Surh dow patterns are season to nature. The normally small budget at the disposition of the average farm kroup, and the limfted avallabllity of sidlled labor (suck as carpentery and masons), constraction materials (often under the control of the Government), and needed equipment, provide further constraints to construction work. Geverally the organization at the community level in Afghanistan is limited insofar as construction experience and the requisite tecknological knowledge is conosrned. Such expertise may well be available at provincial or state capital headquarters, but it is frequently difficult to heve this knowledge disseminated to remote areas. Energy limitations, if not thelr outright lack, are adolifonai constraints tereause tiney limit the use of power equipment that might facllitate and improve construction.

4. Operation and Maintenance

At present there is no DRA organization for the operation and maintenance of the small-scale irrtgation systems. The Ministry of Water and Power has indicated that it plans to have a section in their new organization for this purpose. However, it expects that a country-wide speration and maintenance program for the private, sinall Irrigation systems lies ten years in tho future. RDD does have a maintenarce section but it Is greatly understafied and there is no budget for implemeritation operations.

Local organizations for system operation and maintenance exist at 
the community level. The structure of such organlzations ciepends malniy on the size of the tadridual system. Organizational operations are hampered by lack of administrative competance and technical shortcomings. With proper hydraulic design, small-scale Irrigation systems would be much easisr to operate and maintaln. There is virtually ao control of the amount of water entering these systems (except for a few systems that have benefited from RDD-assisted hydraulic desiga). Protection from flooj damage is minimal. The amount of water bears ilttle relationship to crop requirements. The comraents inade under "Construction" concornlng materials, equipment, labor, and budget are equally applicable to the operation and matntenance of small-scale irrigation systems. The lack of government regulations is conducive to permitting inequitles in the use of water.

5. Losses

An on-farm irrigation supply system is subject to many losses which can materially reduce the flow originally diverted from the river. These losues, which have been estimated for Afglianistan to average about 65 percent of the total supply (or, indeed, all of the supply in the case of a major structure destroyed through uncontrolled llood flows) are caused by the following:

- Seepage through pervious solls through which the conveyance 
system is axcavated.

- Inadacuate hydraulle desiga. In this Instance it could ccatribute, through oversized conveyance channels, to Increased seeprge and excessive canal excavation.

- Evapotranspiration from large plants, shrubs and busbes contiguous to the conveyance system.

- Aquatic zrowth within the conveyance systom impeding normal Irrigation dows, and also contributing to evapotranspiration losses.

- Inadequate Iood protection of principal structures which could expose such structures to damage chring floods, with a consequent loss of Irrigation flow as has been noted above.

\section{Recovery Sygtems}

Recovery (drainage) systems are usually needed to prevent warerlogging, or to iroprove waterlogged solls with attendant high salinity. In Aighanistan there is a tandency for water users at the head of a supply system to appropriate more than their falr share of irrigation water, a practice which if unchecked and uncorrected usually eventually leads to water iogging. This state of affairs is a reflection of the established social structure which unintentloally encourages lax and inefficlent water management: andi in so doing certain water users, because of their sncial position, to exceed their water allotments. 
Uniavcrable land configurations whtch have not beva ameliorated through levelliog or terracing can also lead to waterlogging problems, ag can the prevalence of high water tables and unfavorable (i.e. lowpermoablity) solls. This last is not too widospread a cosstealnt, as many of the solls in Afghanistan are more pervious than otherwise. Water recovered through the operation of drainage systems may be retarned to the river, or used to replenish groundwater aquifers; in some cases, water recovered from a drainage sysiem can be further uttilized for augmenting an irrigation supply.

\section{PFFECTIVE DEMAND PROBIEMS}

1. Land Configuration

The natural terrain features generally found in indigenous community irrigation systems (which, in Afghanistan, deliver water to approxirately three-fourths of all irrigated land) require substantial modification before efficient surface irrigation metloods car be applied. Farmers have managed to effect a measure of land levelling by their own dertces over the years, but mostly on a field-by-fleld basis. This has resulted in odd-shaped and uneven-sized fields with no precision grading, which has ccupplicated the internal farm distribution system and obviated uniformity of water application to the flelds. To compound the farmer's problem further, there is pirtually no source of technical expertise avallatle to 
survey and desigp an efticlent on-farm Irrigation system, nor are land improvement contractors and appropriate equipment avallable.

2. Soll. Wator, and Plant Relatlonshíps

Kinowledge in Afgharistan concerning the interaction of soil, water, plunts, and fortllizor is mostly concentrated at centrally-lxated research and educational institutions. Disseminating this inforroation to rural subcenters, and through them to farmers or farmer groups, has not been adequatoly implemented. Extension work ts carried out by the Ministry of Agriculture, but its responsibility in this area does not include the education of the farmers on soll and water matters relevant to irrigaticn practice. This is administatively the responsibility of the Ministry of Water and Power, but circulation of such information to rural areas has not yet been Implemented.

\section{Agricultural Practices}

Farming procedures for crop production in Afghanistan appear to be fundamentally tradition-bound. Modernization of these antiquated practices is hampered: first by an Inadequate information system to educate the farmer, and then by a fallure to provide sufflcient encouragement, Lacentives, or uneans for the farmer to effect many such improvements. Existing practices where improvenents could be made are included 
in, but not necessarily llmited to, the following llsting:

Land fraparation

ligh yigldiug varietles of seeds

Destrable dates for seeding

Sowing rates
Methods of irrigation

Control of weeds, insects, and disease Fertilizer usage

Use of proper tools and equipment

Additional constrainis originate in the exfsting social structure.

Local power relationships impose conditions that aro beyond the farmer's means to overcome. Such a relationship is apparent within the community Irrigation systems, where mirabs are selected by the firga, or councu of elders, and where consequent favoritism. appears to be the norm rather than the exception.

The lack of a crop-reporting service and a minimum-price-support program, announced in advance, affects the farmir's planning. In practice, it confirms bis preference for achering to traditional cropping patterns.

\section{Water Management}

The first phase of water management in irrigated agriculture is concerned with the delfvery of water from the conveyance system to the farm.

The second phase is concerned with water management on the farm itself.

Water should be distributed among the canals and laterals in proportion to the area of land to be irrigated on a rotation period basis. 
However, In most of the supply ststams in Afghanistan there are no gated intake or turnout structures, and as a consequence prater daliverleg ramot be fixad in terma of predetermined quantity per unit of irrigated area.

Water management on the farmer's land is essentially the control of tho amount of waier needed by crops at a particular growth stage, and the time and frequency of application as dictated by climate and soll characteristics. These concepts are neither understood nor practiced by farmers in Afghanistan except in a rudimentary, empirical way, strongly influenced by tradition. The problem in disseminging o odern water management principles is similar to that proviously descrited for soll, water, and plant relationships.

A further afgravation concerning current water mismanagement is the fairly common practice of farmers at the head of a distribution system acquiring, through traditional use patterns, an almost incuntestahle right to the use of a greater volume of water than those located lower down in the system.

5. iJon-Farm Demands

In many of the community irrigation systems in Afghanistan, particularly those in more remote locations, requirements for domestic use of 
water, viz., potable water, laundering, fuod cleaning, and livestock wrtering, aro met from Irrigation water suppiles in the Irrigation canals (jule) which are made to pass through or near to the village. With respect to farm irrigation, the problem may not be souflcant considerIng only withdrawals for ccrsumptive use. However, the pollution factor arising from the introduction of deleterious substances such as household sewage wastes lncluding night soll, detergents, soaps, or other chemically non-biodegradable substances into the irrigation stream couls affent water quality. The hibhest non-farm consumptive use comes from growing trees planted alung the jul.

D. IDENTIFICATION OF PD INCIPAL PROBLEM AREAS AND CONSTRAINTS Further intensive studies and discussions of causai effects, interrelated impacts, and the relative importance of the key variables just described were made. As a consequence, problem areas began to emerge, areas that embraced many of those elements which infutenced the variables themselves. The firal analysis in this Section of the Study concluded with an identification of what appeared to be principal problem areas and the most important constraints affecting those areas.

These main problem areas were found to be:

- Resources 
- Conre, ance systerns

- Vtulzation

The following paragraphs describe the major constraints that were constdered to influence these problem areas.

1. Resources: The analysis of this problem area led to the conclusIon that a fallure to optimize constituted the major constraint hampering the development of Afghanistan's soil and water resources for irrigated agricultural applications.

Insofar as water resources with irrigation potential are concerned, there is a lack of knowledge concerning locations of sources, water quality, and water quantities avallable, focluding a categorized eraluation of prior claims on surface and groundwater supplies, as well as seasonal variations over a substantial number of years.

2. Conveyance Systems: Five key constraints were apparent during the course of the aulysis of this subject:

a. Dlversion structures are inadequate and in some cases may not be the most suitable means of diverting water for irrigation use;

b. Seepage from the system impairs efficiency and is the chief cause of water loss;

c. Inadequate flood protection is responsible for substantial 
water losses uatll repalrs can be effectod;

d. Convey:ace control structures are lacklng or inafequate:

e. The social organization affecting water control and distribution is not fully responsive to farmers' needs.

3. Utilization: Three key constraints were found tn be hampering efflclent utilization of irrigation water on the farmer's land:

a. A lack of knowledge by both technician and farmer of efflecent water-use practices;

b. On-farm infrastructure related to efficiemt water use is either lacking or inadequate;

c. Current farming practices and the lack of a soll improvemeit program are hindering the efficient use of on-iaren Irrigation waicr. 


\section{POSSBBLE ALTERNATIVE SOLUTIONS}

\section{Introouction}

This Section describes pesalble solutions which have been considered as being respoisive to the three major problem areas as defined in Section I, C.

\section{A. PROBIEM AREA; RESOURCES}

Basic constraints: Lack of knowledge of quantity and quality of resources; measures required fur effective utllization; need for exploitation and conservation regulations.

Possible Solutious:

1. Establishment of a National Water Resources Commission. A National Water Resources Commission would be an autonomous cosrdinating and policy-making group for the purpose of reviewing and approving all major water resources projects before operating funds were made avallable. The organization character, staffing and responstbllties of such a Commission are given in Appendix 3. Its authority, however, would cnable it to implement the following actions; these activities themselves constitute posstive solutions within the Resources problem area.

a. Inventory of all significant surface woters and groundwaters; 
b. Upgrading of the hydrometeorological network to fuprovo the callber of the data obtained and roculred for water resource prolect planning;

c. Investigaticn of principal groundwater sources through drilling and pumping (drawdown and recovery) test exploration programs;

d. Investigation of more effective and efficient means and measures of water resource utilization such as, but not limited to, the artficial recharge (see definition bolow) of developed groundwater sources; consideration of ruroff irrigation (from a water avallabulity standpolnt only).

2. Implementation of an immediate groundwater develogment program for selecter areas.

The implementation of such a program would not be dependent upon the establishment of the aforementioned Commission, but would zequire a prior groundwater inventory to be made of any designated areas for such development.)

This program would comprise the following elements which would be implemented in selected areas of Afghanistan to improve and increase exIsting and new sources of irrigation water:

a. A well-drilling program limited to relativery shallow wells (not exceoding $25 \mathrm{~m}$. in depth where small-bore rigs are 
arauable);

b. The enhancement of developed groundwater resources by artiflcial rechange. (Artiflelal recharge is tho term used for Introducing water, either through percolation through the soll using any of various arrangements of surface application, or by injection Into a water-bearing soll stratum, known as an aquifer.)

3. A comprehensive soll inventory and description.

A soll Inventory would describe the soils of different areas and the description would be coded and incorporated on soil maps. Soll maps are a basic tool for seiecting a system of soil management. The maps show the kdnds of soil in a fleld and farm -- essential knowledge for selecting from the varlous arallable soli-management practices the combination of practices that is best suited to the soil and to the resources, skills, and desires of the farmer and rancher.

Interpretations of soll maps are physical and economic analyses of the alternative opportunities avallable to the users of the land. They indicate capabulities of the solls for agricultural use, adapted crops, estimated ytelds of crops under deilned sysiems of management, presence of specific soll-mazagement problems, opportunitles and Ilmitations for varfous management practices, and problems in nonagricultural use. 


\section{A soll and wator consorvation program for irrigated catch- ment areas.}

Soll and water conservation within an irrigation basin concerns the protection of soil resources against erosion and the improvement of tho water comrol system. Conservation measures to effect this would include:

a. The inposition of controls affecting srazing, the felling of trees and the harresting of other plant life, and burning;

b. Vegetative activities such as afforestation, and the seeding of selected grasses, forbs, herbs and shrubs; and

c. Cunstruction operations such as terracing, and the installation of dikss, levees, diversion and contour ditches, and other water-detention facilities.

5. Construction of surface water stornge reservoirs.

These storige reservoirs would store water for future irrigation use. They could be formed by sizablo structures across rivers; the resulting reservolic could have considerable capacity, with carry-over storage from one saason to the next. Smaller reservolrs, or ponds, could be formed from embankments or dikes, and could store water temporarily from varlous sources, such as irrigation flows on certain farm areas, overland rmofi churing high-intensity ralnfall, or flow recelved from subsurface sources. 


\section{B. BRORLEM AREA: CONVEANCE SYSTEMS}

Baste constra:nt $(B-1)$. Current diversion structures need to be Improved and other means of cupturing water veed to be investigated. Posslble Solutions:

1. River Dlversion structures.

Permanent structures. Where rivers can be spanned cconomically by a weir, a permanent struct:re diverting the river flow to the conveyance system could be considered; this would elther upgracie or replace an existing installation. The structure should be designed to withstand a tlood baving an estimated peak frequency of one in 50 years. The elemeuts of the structure should include shulceways for silt control, control gates at the canal intakes, and an overflow weir to function as a splllway.

Semi-permanent structures. For other wider river locations where the above-described would be obviously uneconomical, a semi-permanent structure employing gabions (wire mesh prisms fulled with rocks and laid in place like riprap) could be considered. Such a structure should be destgned to withstand a flood having an estimated flood frequency of once to 10 yoars. The structure should, however, Lnclude a permanent headgate and sluiceway, notwithstanding the knowledge that because of river aggradation, or degradation, or course change, modification to or even 
relocation of the Intake might be required in the future.

Relocation of existing diversion structures. Where additional benofits would be possible such as:

a. Improved esnal characteristics (non-slit!ng or non-scouring velocities);

b. Abulty to Irrigate more or better lands; and

c. Greater protection from rifer action afforded to the structure;

then relocation of the diversion structure could be considered.

Consolidation of existing diversion structures. Where separate irrigation systems are contiguous or in close proxdmity, and where the topography is conductre, economies in maintenance and operation may often be realized by consolidating the separate diversion structures into one. A few connecting canals would be required to interconnect the exdsting systems, and adjustments would also have to be made in the carrying capactty of certain main canals. Reductions should thereupon be realized in orerall canal maintenance needs, seepage losses, and other losses that inight be attributable to the poor hydraulic design of the original systems before consolidation.

\section{Other Irrigation Supply Schemes.}

Pumped water from surface runoff sources. Pumps could be utlized to provide Irrigation water from rivers. Unnecessarily long canals could 
thus be ellminated, and with them attendant losses. Pump diversion wrould also obviato the noed for run-of-river diversion structures, but would require sidlled operators with a koowledge of malntenance procedures as well as ar energy source. Alternative energy gources to fuel and electricity (in long-tern considerations) could include wind and solar power.

Pamped water from karezes. Dependent upon the capacity of the aquifer tapped at the uppermost karez well, the suitabulity of arable laild in its vncinity, and the assurance of a favorable $B / C$ analysis, consideration could be given to replacing the karez system with pumps at the uppermost well and at the outlet of the system (tapping the aquifer itself at that point). If feaslble, this would enable more iund to be irrigated and would obviate the periodic and hazardous maintenance of the karez now required.

Controlled flow from karezes. Instead of permitting the harez to How continuously, the karez low could be collected in a pipe, thus providing a means of transmission paralleling the karez tunnel. If equipped wth a valve, the pipe system coulc be closed when trrigailon flowe are not required, thus allowing unneecied flows to be stored in the main suppiy aquifer. Alternatively, karez now could be stored in a small reservoir, to be used when needed.

Baste constraints $(B-2)$ Seepage within the systein is the chief 
cause of water loss and lowered effictency; and poor madntenance is a furtier source of loss.

Possible Solutions:

1. Lining of canals.

The lining of canals on a selectlve basis would minimize seepage for those systems where such losses are considerable and critical. Linings are usually relatively permanent (clay linings bave considerable shortcumings and for several reasons would not be rxcommended) and are of three distinct types:

a. Rigid - using cement or asphaltic concrete paving cast in place or formed from precast slabs;

b. Membrane - linings prefabricated from plastic, butyl rubber, or compounds of asphalt combined with jute, paper, or fiberglass. Such linings are either exposed or covered with a layer of soil and sand; and

c. Sealing compounds - liquids sprayed on ditch faces to reduce seepage either by dispersing clay materials, or by filling soil pores to form a membrane.

2. Shortening of lead canals.

This possible solution has been referred to in the previous discussion of Solution A, 1. 
3. Improved Maintenance.

During lood seasons many of the primitive trrigation systems are subject to hows for whlch they were not des!gned. In addition to carrying and depositing a heavy silt load in the canal, these flows are conducive to over-topping of banks with consequent cave-ins, and the general impairment ot the conveyance system.

During other periods aquatic growth and weeds have been allowed to grow in the canals.

Improved maintenance would provide for a regularly scheciuled excavation of silt, the clearing of aquatic growth, the removal of obstacies, and the repair of damaged canal sections. These deficiencies impede flop and also contribute to excessive losses.

Basic constraints (B-3) Inadequate flood protection causes major water losses.

\section{Possible Solutions:}

1. Headgate control structures.

There are almost no permanent intalse or headgate structures for diverting water from the rivers into the main carals of the irrigation systems. The main canal is consequently subject to damaging flows during high river stages; this causes erosion and orer-topping of canal banks, inundation of croplands, and slltation of the cailals. 
A permanent or semi-permanent diversion structure with headgato controls to canal and sluiceway would prevent this recurring damage. The permanent wels section could be masonry or concrete, with gablon corstrection for the semi-permanent diversion structure. The headgate or regulating structure could be masonry.

\section{Slphons}

Inverted siphoss could be used where irrigation ditches cross roads, canals or st:eam channels. The conpeyance system is this protected against damage from imcontrolled flows in the channols and impedance of tlow from other sources is obviated. Siphons may consist of a concrete bex structure or a plpe (either concrete or steel). Thelr design must be based on adequate hydrauiic malysts.

\section{Flumes}

Flumes could also be used to carry irrigation water across small waterways. Their cost is usually less tian an inverted siphon, but they may require more maintenance or earlier replacement, and the necessary supporting sub-structure might not be practical in some locations. Flumes could be marle of pre-cast conerete, sheet metal or wood.

4. "Cut-and-cover" canal sectiong

These sections could be used to convey water where canals cross waterways, or traverse steep slopes where debris deposition or slides are a 
problem trom the slope above the canals. Such a conveyance has a rectangular cross-section, and is so cxcavated that the structure will be below ground surface. The sides and bottom are usually rubble masonry with a pro-fabricated concrete slab placed on top of the masonry walls. The structure is then covered over with fill material as necessary.

\section{Diverston Dikes}

Diversion dikes, or guide levees, could be constructed for channeling rainfall rwnoff which collects in waterways above fills and canal banks. These usually originate above the canals and continue for short distances below, thus confining such runoff and preventing it from destroying long sections of canals. Such diversions or dikes could also keep runoff from inuodating irrigated land. Construction could be effected with earth fill matertals, loose rock, concrete, or masonry walls.

\section{Sluiceways}

Sluiceways cruld help prevent canal siltation by removing silt or other matter from the bottom of the Intake channel before it has a chance to get into the canal system. Sluiceways are frequently incorporated wtth the headgate structure.

$$
\text { Basic constraints (B-4) Irrigation water control structures are }
$$

lacking or in need of improvement. 


\section{Posstble Solutions:}

1. Divislon boxes.

These structures could be used to divert irrigation water from laterals to secondary canals, from one field ditch to another, or divtde a stroam between two or more laterals or ditches. The division boxes are generally box-like structures, bullt of rubble : masonry or concrete with two or more outlets (comrnonly called turnouts) used for the delivery of water. The size of each outlet would be proportional to the amount of water delivered. Gates would be required for closing or regulating the flow into each separate outlet. The outlets of many division boxes are metered so that measurements can be made of the quantity of water.

\section{Cinecke.}

Checks could be placed across canals, laterals, and field ditches to raise the water level to the elevation that would enable the required amount of water to be released to a field. The water level should be kept at noarly the same height above the ground surface for the width of the fleld being Irrigated, so that thow into each of the basins, sontour borders, or furrows will be equal. Permanent gates could be used in checks, or they could be equipped with flash boards or undershot sliding gates to control the water level.

3. Outlets or turnouts. 
These devices could be used for releasing the Irxigation water from a canal or ditch to a fleld. They would control the amount of water boing diverted lato each bagin, contour border, or furrow. The cholce of outlet would depend on method of Irrigation being used.

\section{Drops}

Drop structures could be tzatalled in ditches on land with considerable slope. These would pormit the ditch to be constructed as a series of relatively tiat channels, each at different elevation, at non-erosive grades. They should be geverally spaced so that the difference in elevation at each drop does not exceed $50 \mathrm{~cm}$. Drops dissipate the energy of the falling water using a stilling bastn with a concrete or rock apron, so that it does not erode the ditch.

\section{Metered gate structures}

An accurate determination of how efficiently Irrigation water is being used is dependent upon the measurement of that water. Sufficlent metered gates for this purpose could be mstalled in arops, checks, or turnouts. A metered gate is a fixed dimension opening calibrated for measuring the streamflow over or through which irrigation flows pass. Such measuring derices measuise the rate at which water is being delivered. They may consist of weirs, orifices, Parshall Aumes (generally employed by technicians making water-use studies), and commercial gates callbrated by the manufacturer. 


\section{Closed Pipe Distribution System}

Pipelines could provide a number of advantages over opeu ditches for the distribution of irrigation water. In recucing seepage losses, they would be comparable to concrete-lined ditches. Evaporation losses would be ellminated and weed control unnecessary. The area that would otherwise be occupled by open ditches could be planted to crops. Generally, maintenance costs would be less than for open ditches. (Increased use is being maw of pipelines in areas where water savings, costs, or the full use of all Irrigable land are important considerations.) Pre-cast, non-reinforced concrete pipe is the most widely used type for Irrigation pipelines of low pressure.

Basic congtraints (B-5) The social organization of water control and distribution is not fully responsive to farmers' needs.

\section{Possible Solutions:}

1. Training Program for Mirabs and Chakhbashis. Mirabs and chakhbashi assistants are currently responstbie for managing the community irrigation system. They opersee the distribution of water from the main canals to the sumerous laterals along those canals; they settle disp-tes involving the use of water; and they organize the water ugers for both periodic and emergency maintenance and system repair. Despite their unfamiliarity with hydraulic concepts, mirabs and chakhbashis do a fair job of distribucing water throughout the systems. 
To improve overall efficiency in water use, the mirab and chakhbashi could be given some basic tratsing in both modern agricultural pructices and elementary hydraulic princlples. Following these instructions in the proper distribution of water within thelr systems, monitortog of the degree of assimilation and the effectiveness of this training fould be administered by the same artency responsible for the initial teaching program.

2. Operation and Maintenance Standards.

There is at present no governmental agency that is effectively concernod with the operation and maintenance of sma!l-scale irrigation systems in Afghanistan. Such work is currently implemented through communal actions headed by the mirab, using simple tools and primitive techniques piacticed over mayy years.

The establishment of standards for the operation and matatenance of small-scale conveyance systems prould increase the effictency of thi?e systems, assuming that the agency responsible would assist in providing material, equipment, and a source of financial assistance for this work, as well as concomitant training and supervision.

3. Water Rights

Water rights in Afghanistan are based upon Islamic Law, which in effect states that water is a iree, natural resource which is to be shared equally by all and not to be sold. Accordingly, land owners in each region heve 
derisod a system whereby the Irrigation water is allocated proportionately, lissed upon the stze of land holdings. Althorgh this system of water llocation is somewhat crude, it could theoretically work. In practice, however, traditional rights are sometimes ignored by powerful large landownors, by landowners at the heads of irrigation systems, and by other unscrupulous water users. Consequently, those at the lower end of the system often roceive less water than they have a right to.

The enactraent of water rights lerislation could contribute to the equitable and afficient use of water in Afghanistan. Such legislation would be concerned with nation-wide standardization of water use for eacn reglon and for each crop, as well as enforcement of the vewly legislated $r$ tghts to Irrigation witer.

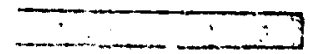

C. PROBLEM AREA: UTIZZZATION

Basic constraints (C-1) There is a lack of knowledge by technician and farner of efficient water-use practices.

Pussible Solution:

Initiate research: develop irrigation gulies; and give technician and farmer training courses.

Research could produce data on proper rates of water application based on locsl soil/water/plant relationships.

Irrigation guddes, developed for each locality, could indicate the 
proper method of Irrigation for each crop, rate of application of irrigation flow, duration of time required to irrigate a given area, and the trequency of irrigation according to type of plant, soll texture, ard depth.

In-service training courses could be given to technicians and subprofessionals that would teach them current developments as well es established, approved practices related to irrigation agriculture. information learned from these courses could then be disseminated to farmers on a broad basis. Farmer training could further be carried out throush fleld demonstrations, informal classwori exercises, and through the use of modia facilities avallable.

Field agents could be supplemented by local village workers recruted from among the more progressive farmers. They would receive some anthe-job trafing, and be required to assist in promoting production campalgns within the village. They would receive a small salary, but cominne with their farming operations.

Basic constraints $(\mathrm{C}-2)$ On-farm infrastructure related to water-use efficlency is either lacking or inadequate.

Possible Solutions:

1. Improvement of on-farm distribution system. Many of the possible solutions for Conveyance Systems previously described 
(see Section V Basic Constralnte $B-2$ and $B-4$ ) would be applicable to on-farm distribution systems but at a much rectuced scale. Additional control devices to regulate water onto farmers' flelds are somewhat different, howerer. For this function, stphon tubes formed of plastic pipe or hose coula be used; lath boxes (splles) could be made, inserted through embankments, and pluzged with sod when not being used; o: tlle pipe could also be considered for installation in embankments or legees that could be uncapped when water is required.

Concrete blocks, fired brick, and rubble masonry could be used for the small structures suggested; other than cement, and materials for making these structures would be avallable locally.

\section{Levelling of the laid.}

All surface methods of irrigation require a smooth land surface for uniform distribution of water. Good land preparation to obtain this smoothness is the first step in installing any surface irrigation system. Such preparation could be conducive to more efficient control of water; improved surface drainage; rectuced soll erosion and fertility loss; and possible Irrigation of a larger acreage with a limited water supply due to a more effictent use of water.

Several degrees ot land preparation could be considered, depending upon the nature and extent of the specific problem: 
3. Land smoothing is the removal of mfnor irregularitles of the surface without altering the general topographic p.ttern. The practice is applicable to nearly level land, or land with slight or trregular slopes;

b. Rough grading is the removal of knolls or ridges, and the fulling of gullies and other low areas. These represent greater Irregularitles than thcse described under land smoothing. Cuts and fulls are relatively heavy.

c. Land levelling is the reshaping of the land surface to a planned grade, and usually consists of levelling the surface of each fleld to a single plane or serles of planes. These planes could slnpe both in the dirention of irrigation and at right angles to this direction (as in furrow irrigation); or could slope in the direction of irrigation only (as in border irrigation); or could be level in both directions (as in basin irrigation).

3. Improvement of on-farm drainage. Effective drainage, both surface and internal, is essential to successful agriculture. There is little point in irrigating a crop during the early part of its growing season only to have it damager before reaching maturtty by poor drainage.

Whero land is not naturally reil-dratied, artificial drainage could 
be provided bofore the Irrigation system is installed. Natural watercourses could be used to carry away lood runoff, thus proventing inundation and erosion. Artiflclal drainage works could ellminate wet spots occuring in flelds bocause of seepage from hlllsides or from irrigation canals or laterals, and could be used to remove standing water from depresslons where an accumulation of white salts on the surface of the soll is sometimes noticed.

4. Augmented water supply during droughts.

Where an adequate and convenlently-located aquifer has been identified, consideration could be given to the construction of a shallow well which woyld provide an ixrigation supply for oze or more farmers' flelds.

Basle constraints $(C-3)$ A soin improvement program related to water use is urgently needed.

Possible Solutions:

1. Increasing of fertility levels.

The need for expanding the productivtty of Afghanistan solls is apparent. Fertility levels could be raised through fertilization and soll amendments, which would provide a replenishment and emrichment of major nutrient elements in the soll for optimum plant growth. The extent of such replenishment could be determined from a soll fertllity analysis which would Indicate inherent fertility levels.

2. Reclamation of the soll 
Reclamatlon ls zeeded in many areas oí Afghinistin to remove deleterious or excessive salts from the plant root zone of the soll proflld. Chemical trecitment of the salts (where indicated by soll tests) together with drainage and leaching could provide the basis for the derliopment of a more favorable environment for soil/water/nut: lent interaction and consequent pleat growth.

\section{Subsolling}

Some areas of Afghanistan bave soils with limiting ox barrier layers; these comprize zones of more compacted soll materials, or concretion layers within the so:- profile. These conditions limit plant root development and rostrict internal soli drainage:

This problem could be corrected by subsolling to break up or shatter the impervious or semi-impervious layer in the subsoll. This would enhance water infiltration rates; would afford the plant root more of the soil proflle zone for its development, and respiration; and would improve internal drainage.

Basis constraints (C-4) Current farming practices are not conducive to efficient water use.

Possible Solutions:

1. Land preparation, proper seeding, fertllizer application, and weeding.

Land preparation includes plowing; barrowing; smouthing the soll; 
the forming of ridges to separate border strips or basins for closegrowIng crops; and the forming of furrows for other crops, particularly root crops.

Proper seeding using quality seeds in a more organized fashion would contribute to better plant distribution, whereby plants in a row are systematically spaced to encourage equal soll molsture zones from which moisture and nutrients can be withdrawn.

Fertllizer application at the recommended times and ratee would facllitate the growth of more vigorous plants with well-developed root systems; these would penetrate further into the soll, tapping moisture from a larger soll-molsture zoze.

Conirol ỗ weeds would eliminate competition for available soll moissture and plant nutrients and would accordingly encourage plant growth and derelopment.

2. Cropping systems, including rotation and interoropping. Rotaticn means growing a warm and a cool-season crop, leaving the land fallow; or growing a perennial crop in systemized sequence to maximize land use. Either procecture would stimulate increased prochuction. Many rotations could be developed.

Intercropping refers to the growing of two or more crops simultaneously on the same plot which do not interfere with each other at harvest. Possible examples would be the over-seedirg of wheat with clover; a 
mixture of clover and wheat in an orchard; climbing beans in maize (corn); or the intermixing of two vegotables.

Basic constraint $(C-5)$ Runofi Irrtgation is not belng considered in many areas of Afghanistan.

\section{Possible Solution:}

The basic objective of runoff irrigacion is the interception of the maximum amount of ralnfall ranoff through impoundment ard subsequent percolation to and retention within the plant root zone. Its practice is applicable to semi-artd areas with an annual rafrfall of at least $100 \mathrm{~mm}$.

Natural runoff from rainfall is intercepted and diverted to elther microcatchment areas or to terraces; the areas are bounded by low earthen or rock-filled walls. Openings ia the walls function as spillways, allowing excess water to be released.

The practice is simple in concept but somewhat sophisticated in implementation. It could be considered for some extensive areas of arable lands in the country now uncultivated, and it has a potential for materially increasting agricultural production. However, climatic and soll conditions must be well knoxn and conducive to the practice. Moreover, considerable technician and farmer training, as well as contimuous supervision during the inftial years of implementation, should be provided to ensure success. 


\section{V!. POTENTIAL IMPACT OF TECHNICAL PACKAGES}

A. introduction

Fallowing extensive study and discussion of the possible solutions, It was concluded that no single solution could be assigned to any specific subsector problem. Accordingly, techilcal package solutions were doveloped.

This Section describes thess technical packages, identifies the inputs (technical assistance, commodites, equipment, training, and type of financiug) that would be required for their implementation, and discusses their potential impact on Irrigated agriculture in Afghanistan in gereral, and upon the indiridual Afghan farmer in particular.

\section{B. Technical Packages}

1. Inventory. This parkage represents a long-term program involving the Ministries of Water and Power, and of Agriculture, plus the Rural Developinent Department. As the Air Authority has the responsibilfy for oporation and maintenance of meteorological stations and the dissemination of data therefrom, it would also participate in the program.

The inventory package is concerned with the inventory of the natural resources of solls, surface water, and gromowater. It would include the upgrading of solls laboratories; the esqansion to first-class standards of 
the hydrometeorological network and anclllary support services; and Improving the capabllity for groundwater explorations to be made.

This effort would require some inputs of commodities and equipment. Technical assistance has been provided in the past, and a judgment assessment is that more should not be required for inttial wackago implementation. Similarly, foreign training should not be considered untll the project were well underway and specific training neede could be more precisely delineated.

Such an inventory would ultimately enable the nation to know the extent of these resources so essential to irrigated agriculture, as weil as providing the means for ohtaluing basic soils and kydrologic data; these data are needed for Improving planning and desizn operations, and could also be useful in determining the actnal value of Irrigation water.

The individual farmer would eventually benefit as the value of these resources was finaily understood and appreciated, as a more efficient use of solls and water would lead to increased production and, ultimately, as his income would consequently increase.

2. System Infrastructure. This package is concerned with the application of technology to improve and upgrade the irrigation system: diverting water from its source and conveying it to the farms within the service area being irrigated. It covers the utilization of techniques affecting diversion and water control for open ditch distribution systems. 
It assumes an adequate supply of water is avallable, and in this respect ts rolevant to Package I, Inventory.

Diverition structures could be permanent or semi-permanent. Sound hydraulic principles should govern the design of distribution systems, including terminal facilties, with special emphasis on: upgrading of diversion structures; (2) flood protection; (3) water controI structures; and (4) seepage losses (canal lining).

Equipment and commodities would be neejed as well as in-service training programs for professional, sub-professional, and technical staff. On-the-job training could be provided by consultants and expatriates. Grant and credit funding would be needed for the implementation of the tecinicai package.

In addition to the rehabiltation of Irrigation systems and a consequent augmuatation of the irrigation water supply, the package would provide an additional factor favorably affecting increased yields and Improved quality of crops grown, with the ultimate end of increasing and stabilizing the farmers' economy.

3. On-Farm Inirastrictura. On-farm infrastructure is concerned with the physical characteristics of an indifidual farmer's land holding or farm. The elements of on-farm inirastructure included for improvement in this package are land levelling, field drainage, on-faras distribution systems, and on-farm wells. The improvement of these elements would 
permit the farmer to apply wate: and other inputs with greater efficlency. The maximization of these inputs could result in greatly increased ytelds with consterably less labor requirement.

The implementation of a farm infrastructure improvement program would require technical assistanco, training, commodities, equipment, funding for demonstractions and for intermediate-term credit. The Agricultural Bank would be the agency responsible for providing assistance as well as for implementing this program.

In addition to the rehabilitation of irrigatlon systems and a consequent augmentation of the irrization water supply, the package would provide an additional factor favorably dffecting increased yields and improved

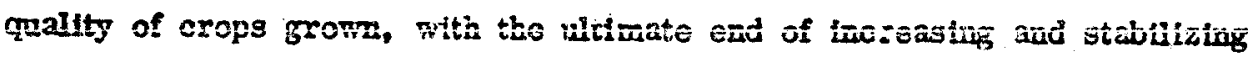
the farmers' economy.

4. Soll Improvement Program. A soll improvement program would be based on soil management principles, and would promots the reclamation of saline or alkaline solls, and the improvement of soil ferthity. Such a program could benefit farmers by increasing orop yields and by improving soll tIth; the latter would enhance water-use efficiency on the farm.

This program would be closely allied to programs for system and On-farm Infrastructures. It would slso be related to both Research and 
Extengion and Training Programs.

Inputs for program implementation would include technical sssistance; training; coramoditles; equipment; and funding for demonstration plots and for credit rosources.

DRA Ministries and agencies which would be involved in the impiementation of the program would be the Ministries of Water and Power, Agricultare; and the Agricultural Bank.

5. Research. A strong regearch program for doveloping and testing varletal response to soil/water/plant and nutrient interactions as well as cultural practices would significantly benefit Afghanistan's agricultural programs. All farmers could potentially benefit by adopting ryore moderu farming practices as deveioped and raiedsed by the nine research institutes in the country.

This program is a vital necessity for upgrading the quality of ex'tengion information to be disseminated to farmers, for developing irrigation and drainage guides, and for testing new technology such as run-off Irrigation. The program would serve as the font of information used in the Extension and Training Program.

Financial Implications ars indicated for technical assistance; foreign training, commodities, equipment, and sowe funding for demonstratloas. The Ministry of Agricuiture is the DRA agency responstble for 
research.

6. Exteusion and Training. The Extension and Training Program is stractured to upgrade the quality of technical advice being given to farmers on farming practices in Afghanistan.

Both the individual Afghan farmer and the country's farming communtty as a whole could benefit from the introduction and adaptation of more modern farming practices that wouli have as their objectivo increased yields and production levels.

This package should begin with a progressive schedule of upgrading the skills and knowlodge of prezert cadre and staff through in-service training. Further sophistication could be achieved through technical assistance and foreign training. The program would noed support for anquiring commodities, equipment, and some fundizg for snonsoring demonstrations.

Implementation wou?d be effected through the Ministry of Agricultore.

1. Groundwater Development. This package is concerned with the necessary ex loration and develofment of wells, springs, karezes and galleries; a program for the introcuction of artffictal recharge; and an extensive groundwater testing program.

The impact of such a program that would accrue to the nation 
would be the increased knowledge of the groundwater resource potential throughout Afghanistion, kncwledge that would be of considerable value in the more efficient utulzation of present groundwater systems; the control of pumping and drawdown; and the planning of futuro irrigated agricultural developments that would be dependant upon groundwater resources Aither as a prime or supplementary source of irrigation water.

The farmer would henefit from a groundwater program where adequate supplies of groundwater were discovered through investigation, or where present inadequate supplies could be increased through artificial rechisge. The increased wat je supplies could Improve crop yields and hence farmers' incomes.

Inputs required would be small amourts of technical assistance; training; and laboratory and testing equipment. Somo additional drill rigs would be seedod to augment present inventories.

The Ministry of Water and Power would be involved in the program's implementation, as well as the Rural Development Department and the Agricultural Bank. 


\section{ADDITIONAL UNEVALUATED CONSTRAINTS}

Although the Team's development of the technical and policy packages was infiuenced by the constraints that have been described in detall In Section IV of this Report, there aro uther passibie constraints or limitations, some of a socio, cultural nature, which although beyond the purview of this Study, should be borne in mind for future reference. These unevaluated constraints (insofar as their impact upon the designated respective packages is concerned) are outlined below. Some of them could significantly influence any decision concerning the future Implementation of the pacikages.

- Tradtional agricultural production methods: The insistence of farmers in adhering to traditional but outmoded methods of agricultural procuction limits and frequently negates many recommended inputs. This has been one of the ront causes of disappointing returns on some major Irrigation projects. Irrigation water is simply one input affecting production: iertilizer, qual1ty seed, and good cuitural practices are equally necessary, for regardless of its appilication, irrigation water applied to sterile sand will not prockuce a grais of whest, a boll of cotton, or an ear of maize. 
Afghanistan desporately needs a program acceptable to its farmers that will induce them to accept progressive agricuitural practices.

- Water law/water rights/water charges: The Team has been showt a translation of a decree setting forth water rights. Field trips to several projects, and the reading of reports touching on the subject, have been unconvincing that a national water law exists, or that water rights are being equitably administered or enforced. There was no indication throughout Afghanistan that water charges are eitber being made or are contemplated. The absence of these elements, so essemtial to the success of many of the solutions contemplated, constitutes a serious limitation to future irrigated agricultural derelopment.

- Soll cchservation: The effectiveness of vegetasive and mechanlcal measures for protecting water catchment areas against further erosion and other deleterious effects of surface runoff would be dependent upon concomitant regulatory controls such as restrictlons limiting grazing, wood barvesting, or burning. Such restrictions could engender adverse impacts where the controls conflicted with traditional practices. Because the program was not corsidered as significant as other possible solutions studled, 
furtber Investigation of a soll conservation program was abandcnod.

- Land Temure: Land reform legtslation was passed during the drafting of this Report. Its full import, and the extent and timing of its implementation, were not avallable to the Team.

- rJational energy and material resources: The relaxation of present restrictions on energy and material resources, eventually permittiog the farmer access to these elements, could sigaificantly contribute to his increased proctuction, and conseguently could influence the possible impact of the packages.

The technical and poltey piskiges havo a'so not been subjected to posstble Ifmitation that could bo Imposed by their relevanee to the USAIO Country Plan for Program Development, its priority committmonts, and Its timing. 


\section{AFGIZANISTAN}

\section{Annex 1 \\ IRRIGATED SUD-SECTOR ASSESSNIENT}

Use of Ground Water and Recharge

to Increase Agricultural Production

by.

Lcovard Schiff, R. E.

Consulting Hycirologist and Agric. Engr.

Kahul, Afghanistan

December, 1978 


\section{TABLE OF CONTENTS}

Subject

Summary and Conclusions

$a, b$

Introduction

Needs Based on Ground Water Problems

Problems - Use of Ground Water

Recominendations -- Ground Water

1. Explore, Inventory, classify ground water (for use of wells)

2. Karezes

3. Infutration Galleries

4. Springs

Artificial Recharge of Ground Water and Development

Devices Used to Evaluate Potential Recharge Site

Method of Artificial Recharge Include

Water Used for Recharge

Work by Farmers

Management 
Tabio of Contents (cont'd)

\section{FIGUNES}

Flg. 1 Stratigraphic Characteristics (Sub-strata) 6

4, 5,6 Karez, Inflitrometers, Soll-moisture Device, Permeameter for Water Movements in Soil 6

" 7 - 13 Recharge Methods 11

APPENDIX 1

Fig. 2 Computation Riso and Fall Ground Water Mounds 15

" 3 Representation Design of Hand-Dug Well 16

"14: Computation for injection method (pits) 17 


\title{
RRIGATED SEB-SECTOR ASSESSMENT
}

\author{
Use of Ground Water and Recharge \\ to increase Agricultural production
}

\section{SUMMARY AND CONCLUSIONS}

There are a Jarge number of wells, both shallow and deep, in Afghanistan to augment surface runoff supplies of wator for irrigation. In times of low runoff wells become an even more important water resource for agricultural production. In some areas ground water is the only source of water (such as the use of karezes). More wells are going in, the tendency is to place emphasis on the shallow hand-dug well to help the rural poor. Generally the rural poor are not on the upper end of distribution systems and thus suffer from insufficient water.

Ground water levels are declining in a number of areas and there is fear, particularly as more wells go in, that declines will continue. Declines are expected in a number of arcas that are being planned for development.

Mr. Asimi, president of Planning, Water and Power, in programs involvIng wells, suggests consideration of artificial recharge (not practiced in Aighanistan us yet). ivir. Ásifi, president of the AgBank stresses the use of wells and is conccrned about the lack of knowledge to select appropriate locations, type and optimum depth of wells, and to predict approximate yiolds. Dr. Raouf, President, Water and Poiver Engineering Company, has also expressed concern over the possibulity of declining water tables in three areas for which plans are being developed. Mr. Said of the AgBants stated "that a number of farmers want to return their pumps to the Bank because their wells have gone dry".

Consequently, It appears that there is an immediate need to arrest the decline and raise ground water levels, starting in areas where there are a relatively large numbsr of farmers, particularly rural poor. To do this an exploratory pregram is needed, using portable small-bore drill rigs, to obtain the follcwing inventcry to provide information enabling: (1) Determination of depth, extent and characteristics of sub-strata; (2) Delineation of the depth and extent of aquifers (water-bearing formations); (3) Determination of depths to water, available supplies, and quality; and (4) Estimation of the capacity of ground-water basins and safe yields.

Such investigations enable selection of the best sites, types and optimum 
depth of wells, yields anticipated. and safe yields (to insure some water supply during periods of low runof and droughts). Additional equipment needed is a test kit to determine water quality (as salinity and alkalinity). Sites and depth of test drillinf are based on existing data available, or trom the exploratory program.

Sources of ground water in a ground water development program inciude wells, springs, karezes, inflitracion gallerles or intercepting ditcbes. Each is discussed bereln including methods to increase water ytelds and/or conservo water, looking toward increasing agricultural production. Ground water is used basically to augment surface supplies of runcff water, however during years of low surface supplles, ground water can become the major supply and minimize the eifect of droughts.

To date ground water has been augmented by seepage from rivers and their sub-systems, diversions and conveyance systems, and over-irrigation. However, seepage is falling short of maintatuing ground water levels. Consequently artiflcial recharge (not practlced as yet in Afghanistan) is necessary now, not only to maintain appropriate levels but increase them where necessary. The water supply for artificial recharge becomes avallable during years of excess runoff. Such water now wastes to deserts or swamps.

Rocharge includes surface methods as grassed basins and injection methods as pits, shafts, trenches, ditches, meandering canals or combinations of these. Over-irrigation, for example, of alfalfa-cropped basins, each basin with 3 pit (exposing aquifer material) can fuifili a iwo-foid purpose, recharge and a cash return (as food for livestock). In addition to the information gathered under the inventory, it is necessary to obtain information on water movements in the surface soll of potential recharge sites. Such information is obtained with manometer-equipped infiltrometers and a soij moisture device, all described herein and references to publicatioas noted (copes left with AD/A). Recharge with good quality surface runoff alsu dilutes salinity of the ground water, an additional benefit.

The programs summarized above are needed now to increase agricultural prodsction in Afghanistan and to help all farmers, particularly the rural poor. 


\title{
MRIGATED SUB-SECTOR ASSESS MENT
}

\section{Annex 1}

\author{
Use of Ground Water and Recharge \\ to Increase Agricultural Production
}

by.

Leonard Schiff, P. E.

\section{INTRODUCTION}

The team leader of consultants from Experience, Inc. suggested that the section on ground water, because of its somewhat distinct natnre, be attached as Annex 1 to the "Irrigated Sub-Sector Assessment". The writer was in Afghanistan from $10 / 16-12 / 7 / 78$. This section follows portions of the "Key Variables" pertaining to ground water as develored by USALD/ Afghinistan, Afghan representatives, and the consultants. Resommendations are considered under "Evaluation of Alternative Technical Intervertions" as developed by AID/A. This approach developed a closer working and personal relationship with the Afghans that enhanned the work to increase, among other things, the water supplies for agricultural production, especially for the rural poor.

preclpitation varies from about $1000 \mathrm{~mm}$. In the higher aititudes to as little as $20 \mathrm{~mm}$. annually in deserts of the southwest. Most precipitation in the form of snow in the mountains is released through the summer and is the primary source of the nation's rivers and augments ground water supplies largely by seepage.

The hydrologic system is composed of ten river systems or major subsystems llowing into four basins (Oxus, Helmund, Kabul and Hari Rud). Only the Kabul outlets into the sea. Some outlet into desert yastes or swampy areas. (Using artificial recharge, some of the water wasted civild be used to augment ground water supplies, particularly slnce ajditional wells, primarily shallow, are recommended in a number of areas by the Ministry of Water and Power and the AgBank).

About 80-85 percent of the population depends directly upon soil and water for their livelihood. The yearly increase in population is about $2.3 \%$. It 
Is a country that cas proudly clain its "fiercely independent", hardworhing people. About 12 percent of the land fof a total of 250,000 square miles or $6,4+4,000$ square kilometers) is culitivated at present. incroases in this percentare can be forescen through proper management of surfaco and ground waters and the use of artificial recharge.

Ground water has existed historically and is augmented by seepage from rivers, subsystems, distribution systems and unintentional over-irrigation by some farmers. As the number of wells increase, the additional extraction of ground water will necessitate the use of artificiai recharge methods and systems in some areas as discussed berein.

It appears that from historical times to the present, ground water varied from mostly low or mildiy to highly saline from various reports and by electrical conductivity measurements made by the writer in a field trip, pH measurements show no alkalinity problems). Unfortunately there is the likelihood that salinity of the soil may increase under present practices. Excessive irrigation on farms, particulariy near upstream diversions or near the head of irrigation systems, actually leached salis from the topsoll, thus ensuring a better environment for agricultural production. Farms lower down have not been as fortunate, particularly from the standpoints of lack of sufficlent water and insufficient leaching. (For the teclinically Inclined, the leaching requirement, IR, is the electrical conductivity of the irrigation water divided by the electrical conductivity of the drainage water.)

\section{Necds Dased ou Ground Water Problems}

Needs related to ground water problems based on field trips, discussions with five Afghan Ministers and their staffs, and the President of the Water and Potwer Enzineering Company and some of his staff, and a review of literature are:

1. Strategic locations and optimum depth of wells, prediction of yields (not only for best yields but assurance to farmers).

2. Increase yield of karezes and possibly springs and consider use of Infiitration Galleries to collect ground water.

3. Artificial recharge to augment ground water and thus surface supplies to maintain and probably increase agricultural production.

4. Management to maintain ground water at "safe elevations" for supply to wells and to minimize effect of low, surface-runoff perlods and droughts (includes training of farmers, technicians, and extension workers). 
There is insuffelent lnowledge as to the quantity and quality of the ground water and how to effectively use this resource. It will be helpful to cite itlinisters and members of their stalfs (Department of Water and Power, and AgBank) concerned directly and (inancially with potentials for maintaining and/or increasing agricultural production in Afghanistan: "( $)$ increase the supply of water by using more ground water (particularly shallow wells), (2) Increase yield of existing karezes (underground tunne! s that tap ground water supplies), (3) Improve distribution and management of water."

Excerpte from a report by Aziml (President of Planning o. 'he Ministry of Waler and Power) and Mc Millan (Water Resources Engineel) 1977, follow: "(1) Agricultural production ciepends largely upon irrigation, (2) Karezes waste much ground water, (3) Nost surface water supplies are unreliable due to recurrent droughts and insuificient storage capacity. hence the importance of timely ground water development, $(4)$ Origins of subsurface water are mostly from rainfall and snowmelt (proportion sinhing into the soll often higher in arid regions), also in arid regions ground water storage is often the most reliable source of Irrigation water, (5) Where conditions are fayorable, the use of one or more aquifers as reservoirs can contribute to the improvement of agricultural productivity and can ellminate evaporation losses, can provide a low-cost distribution system and result in cost savings when compared to surface reservoirs, the development of ground water supplies must not be neglected, (6) Artificial recharge is recommended (not practiced at prescrit), and (7) Tho ivi. I. Subsectios (ininor Irrigation Section) concluded that a potential for ground poter develeprost codits and that farmers are interested in ground water development." if I recall correctly, Mr. Asefi, President of the Agricuitural Bank, indicated at a meeting that additional shallow wells had important potential.

On a subsequent visit to the AgBank, Mr. Mohammed Sald stated "that a number of farmers want to return their pumps because their wells have gone dry." DF. R. Raouî, President of the Water and Power Engineering Co., discussed the ground water situation and two nembers of his staff stated that in the three areas for which they are developing plans, similar problems may occur, (artificial recharge should be considered as disctissed later in this section).

Water movements through soll and substrata generally have not been related to the physical and chemical characteristics of the soil and substrata. Little information exists on water movements through soll and substrata and laterally fron the ground-water tables. Information could be obtanned enabling better selection of sites for wells, determination of the optimum depth of wells and rasagement of the arnount extracted, whether wells are shallow 
band-clug, shallow or deep bored.

Tho Mfinistry of Water and Power is well experienced in constiucting hard-dug wells, relatively shallow atd deep bored wells, and costs. In deveiopment of wells, pump tests, and pumpsets required, consultants have also contributed to this background. This Ministry also stated energy is not a problem.

Moro tnformation is nceded on the capacity of subsuriace basins now used (at least that supplying extsting wells or those that may be added). Such Information will be vital, particularly as more wells go in and guides are neecied as to the type and number of wells installed. The amourt of water that can be safely extracted to increase agricultural production is not avallable, nor is the amount of water that should remain in storage to be used only when it is necessary to minimize the effect of droughts on agricultural production.

Recommendations - Ground Water

1. Explore, inventory, classify ground water (for use of wells).

First, it is desirable to determine the physical aud chemical characteristics of existing ground water basins that are being used and may be used. If suffictent logs of existing wells are available it may be unnecessary to drill small-bore test holes to augment existing inform?tion. These made on existing weils are and will be beipfui in determinirg important groundwater flow characteristics of a subsuriace basin (areas through which water flows, slopes of water tables and ability of substrata to transmit water). Srnall-bore holes should be drilled to a depth based on the characteristics of the surface and sub-surface materials found (usually about 30 meters will be sufficient, as stress is placed on shai?ow wells, although deep wells are not ruled out). Emphasis is placed on helping the rural poor.

It is understood that relatively light, portable drill rigs that may be toryed are available (about $\$ 12,000$ has been cited as the cost of such equipment, hotvever, additional rigs may be necessary). Holes are drilied usually on a grid system as far apart as possible, (based partially on existing information such as logs of wells, profiles of hand-dug wells, seepage from rivers and the hydraulic gradients or slopes of the ground water table). If there is an abrupt change between test hoies, a hole's) inay be drilled between to establish continuity of the different substrata.

The ground water hydrologist need be on a site only long enough to select locations of test holes and to inspect test samples of materials collected 
and to trst water samples for quadity. In this manner the bydrulogist may cover a number of areas in a relarively short time.

Mgure 1, next page, shows a heipfil inetl od of plotting stratigraphic characteristlcs or the texture of soil and substrata found (toometric projection). Also water levels and permeability designations are noted on the fisure. Such information is necessary to deterrine the capacity of the basin, at least in the area tested, and subsisata that may perch wator. Data on such a figure permit determination of the bvdraulic gradients or slope of the groundwater table, (hydraulic gradlents along with the hydraulic conductivity or permeatllity of the substrata and the area through which water flows are key factors in the determination of: al counts of flowing ground water, use of ground water, rise and fall of the ground-water tabla, rectarge, "safe" yield, and management).

Nothing as elaborate as Figure 1 need be drawn. This figure is a copy of a detailed study made hy the writer in one area in South Americ.. (Such information is also needec for selecting sites for artificial ground water recbirge.)

Figure 2, in Appendix 2, has been Included to Indicate a technical approach to estimating the rise and fall of a ground water table. Performance tests and monitoring of selected wells are also important indicators of the aquifer characteristics.

An electric logger can bo used to determine information on substrata characteristics and permeability, although this approach is not recommended for Afghanistan, at least at the present time.

Information obtained above will indicate the feasibllity of not only rsing shallow and other wells, but also using relatively shallow infiltration galleries (coliector drains) or interceptor ditches. It will gride the locations and types of wells used, including band-dug wells (particularly for small farms and the rural poor). Figure 3, Appendix 1, shows a typical design of a hand-dug well. The approach given above is an economical one that may be usej in many agriculiural or potential agricultural areas to obtain essential data for the conjunctive uso of surface and ground waters.

\section{Karezes.}

Figure 4, page 7, shows a cross section of a karez. In specific regard to the use of karezes (additional karezes bave not been recommended by Afghans), it is suggested that consideration be given to enlarging the tunnel where it contacts ground water, at $A$ in Figure 4 , or use a relativelv small intercuptcr there across the tunnel, only if the additional water could be used effectively for farming. 


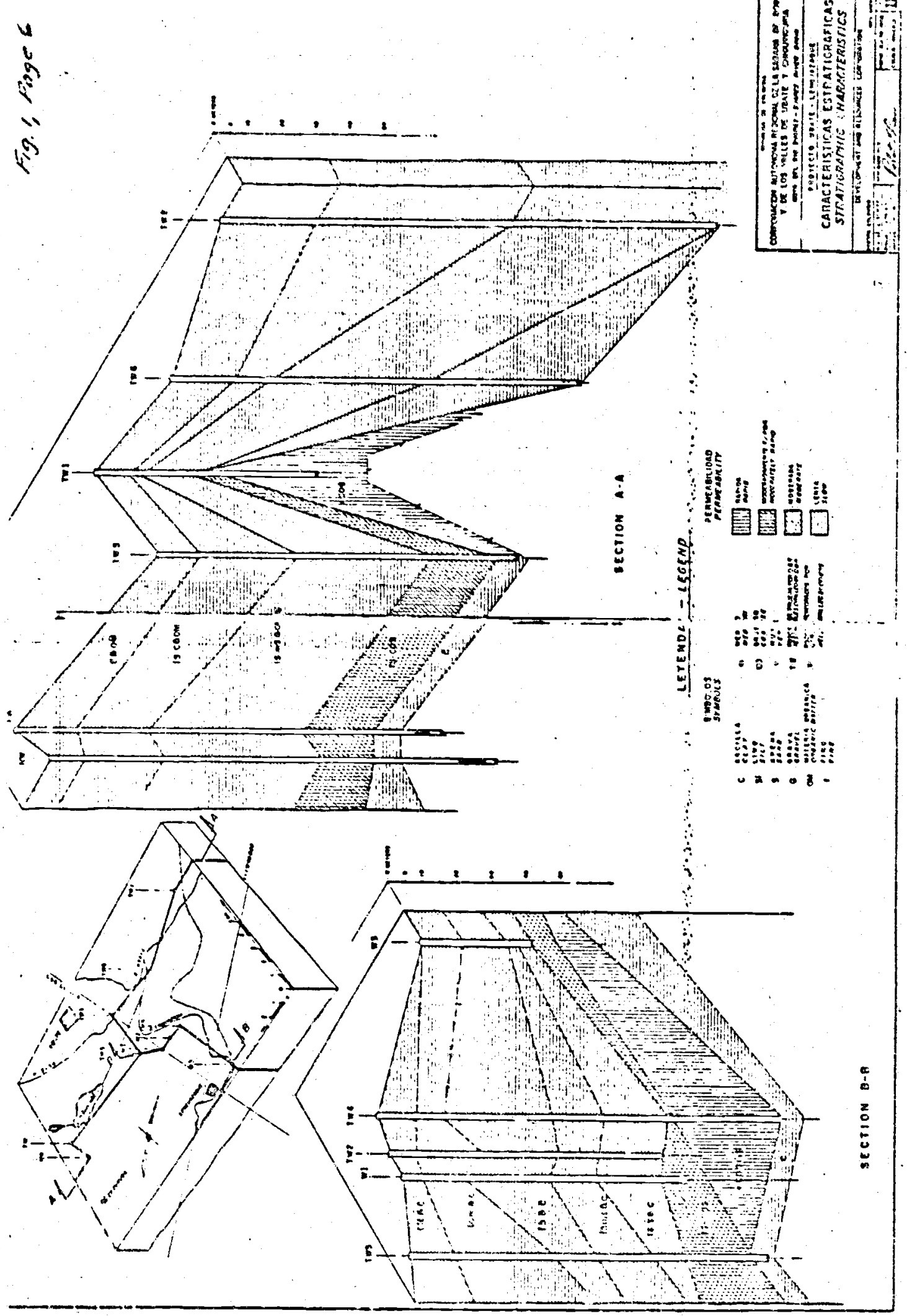




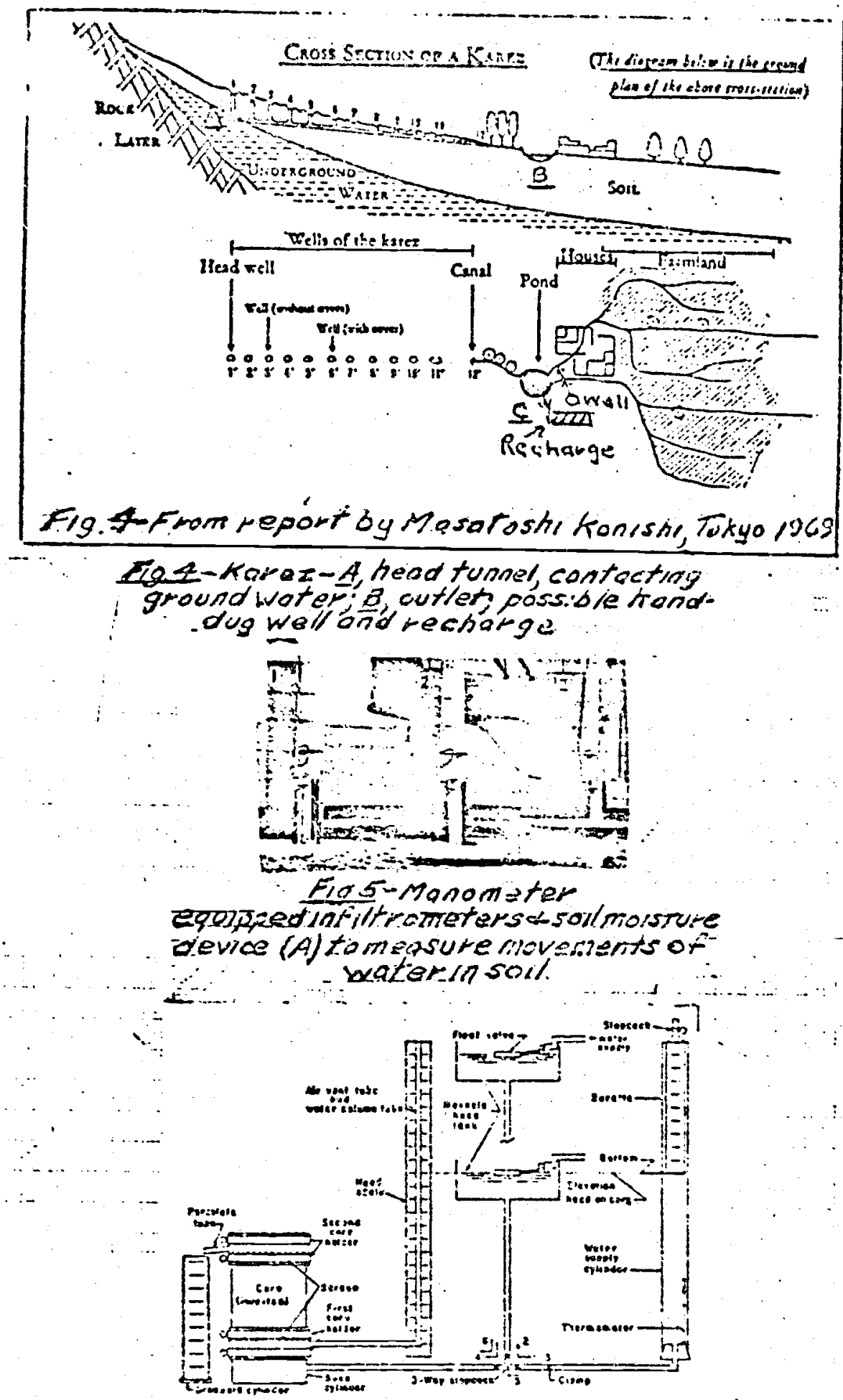

FTG 6-Perweameter for det rminiriz varivus : jil-u utes move! werds 
The movoment of groundwater lnto a tunnel is directly proportional to the contuct srea. However, beforo attempting to increase the flow of a karez it should bo deterinined if thls will reciuce tho flow in a neighborins kare\%.

Water from karezes, outlets at $B$. Figure \&, water wasted at B, should be considered for artificial recharge. Rccharge generally could be practIced slithtiy downstream and around or near a shallow well (usually hand-d"g). C. Figure 4. Whother or not the recummendations concerning karezes are feasible at a given location depends on the characteristics of the site. This approarh may permit farming more land.

\section{Infiltration Salleries}

An infiltration gallery is a horizon!al permeable conduit or dich for intercepting and collecting ground water by gravity tor and is quite widely used (not used in Afghanistan). To be successful it must be located in a permeable aquifer with a hirh water table ard fed by an adequate nearby water source of suitable chemical quality (parallel to rivers, suo-systems, conveyances where depths of 3 to ? ineters are comaion, greater depths usually are not economical). Woter entering a galle $e^{\prime} y$ or ditch flows to a collection sump rhere it is puraped for us?. Based on a field trip, suitable sites appear available in Afghanistan.

For economy, an interceptor ditch sloping dowrward into a distribution system providizy wate: for irrtgetion can be visualized if conditions are right. Small creck dan:s (surt as wire-ard-lock dams) may be needed to reduce velocities in the ditci.

Xialds vary widely, but rates up to 300 liters/sec/300 meters of gallery lengtb are not unusual. Further field investigations of potential use are neceosary. quires investigation.

4. Springs - to increase tow from springs (as enlarging exit) reARTIFICIAL RECHARGE OF GROUND WATER AND DEVELOPMENT

Interest in artificial zecharge has been expressed by Mr. Asimi, President, Planning, Department of Water and Power; Dr. Asefi, President, AgBank; and Dr. Raouf, President, Water and Power Engineering C.o. Artificial recharge is not practiced in Afghanistan.

Artificlal recharge means spreading water on land surface such as basins (formed by ridges around !and s'drfaces) o: small check cams (such as wire-and-rcek) in wide, shaljow river or sub-system with perm- 
sable veds. Injection methods of recharge includes the use of pits, shafts, and ditches or meandering canals in permeable soll.

To use additicnal ground water by installation of wolls where there is not enough natural recharge can be hazardous. The ground water table will decline, wells will have to be deepened, lift costs increased. This had happened in the area where the writer lives (the higbly productive San Joaruin Valley of California, USA). More and more artificial recharge is practiced, particularly during wet years when more surface water is avallable or where there is sufficient stream now or flow is wasted or goes to less desirable places.

A quote from Mr. M. Said of the AgBank stafí at a meeting held Nov. 27, 1978 follows: "A number of farmers want to return their pumps to the bank because their wells no longer produce water."

\section{Devices Used to Evaluate Potential Recharge Sites}

The evaluation of potential recharge sitos and the selection of methods or systems of recharge depends upon relating characteristics of surface soil and substrata to water movements in soil, Schiff, 1964. Figure 5, page 7, shows devices already established for testing the surface soil for the best locations for recharge, Schiff, 1364. Clues are first obtatied by using a soil auger to determine where surface soil and shallow substrata are permeable.

The first step in selecting sites for artificial recharge in areas where recharge is needed is to bore holes with a soll aufer in likely iocations. This determines whether or not the soll and shallor substrata have the moderate to high permeability required, particuiarly for surface recharge. Site(s) need not necissarily be on the land being farmed but can be above where the slope of the ground water table is toward the farming area.

After possible sites have been determined, the next step is to use about three manometer-equipped infiltrometers and a soil-moisture device described by Schiff, 1964. These devices (marked 1, 2, and 3, supplied with water from a metal drum) are shown in Figure 5. The covered metal eylinder, marked "A" in Flarure 5 , is the soil-moisture device. The devires are simple and inexpensive and are used to determine the infiltration curve with time (entry rate of water into the soil), transmission rate (actual velocity o. water, primarily in the g:avity or non-capillary soil pores) hydraulic conductivity of the soil (ability of soil to transmit water), soil field capacity (amount of water held in the capillary or sinall pores), and soil saturation (total vater beld by soil when both capillary 
and non-capillary pores are essentially full of water). A copy of tho publication referred to above ha been left with AID/Afghanistan.

The devices described above are usec to test water movements in soil with a minimum disiurbance of the soil, so that the natural forces existing, primarily capillaxity and gravity, are operative. Figuro 6, page 7 , shows a permenmeter, desigued by Schiff, 1964, for obtaining information on water movements in soil as described above. The device uses soll cores obtained in the field by using a lever device to furce thinwilled metal tubes into the soil. There is some disturbance of the soil but it is recommended over the "disturbed" type soll sample.

\section{Methods of Artificial Recharge Include:}

Surface spreading methods utilize basins, furrows, ditches, "wlld flooding" and streams, check dams (example, wire-and-rock dams) in streams that are wide and shallow and the soil is highly permeable. Injection methods are also used employing gravel-filled shafts (with sand filters), pits and trenches. Wells are used sometimes, but this approach is not applicable to Afghunistan.

Tho basin method is tllustrated in Figure 7, page 11. - It consists of a series of interconnected basins formed by low earth ridges or dikes (can readily be done by rarmers). Grasses may be grown on spreading basins to increase the infiltration rate or entry rate of water into soil. Oae of the best used in California is Bermuda Grass (appears applicaile bite). The grass cover maintains an open friable surface soil of good structure and infiltration rates of 1.2 meters per day were obtained even with considerable sediment in suspension in the water being spread. The infiltration rate, using similar water on a nearby basin with no vegetation, was about 0.4 meters per day. Figure 8 shows a rise of about 2 meters in the ground water elevation in 12 days of basin recharge (neutron probe).

Azother possibility, although recharge is not as great, is to use a crop like alfalfa on spreading areas (called replenished irrigation in the united States). Alfalfa can take a lot of water and also provide a cash return by yielding several cuts as a food for livestock. However, this method (as does Bermuda Grass to a lesser extent) permits recharge plus a cash return. An injection method of recharge, such as a pit dug to expose acuifier material, may be used in basins where conditions are feasible.

As water infiltrates into soil the infiltration rate curve will decline as shown in Figure 9, page 11. The initial decline is largely due to swelling 


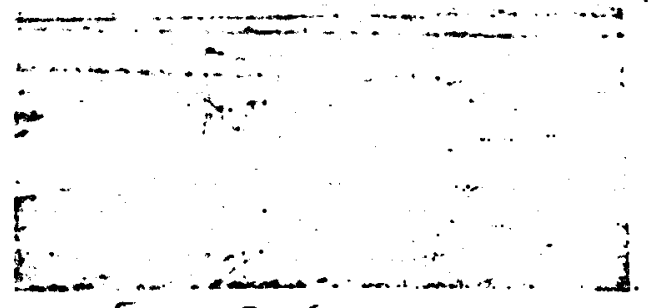

Fiz? Sinferes weethorgis witn ridges rivoring in turcondecting cuans, mith eerosuda grass corer

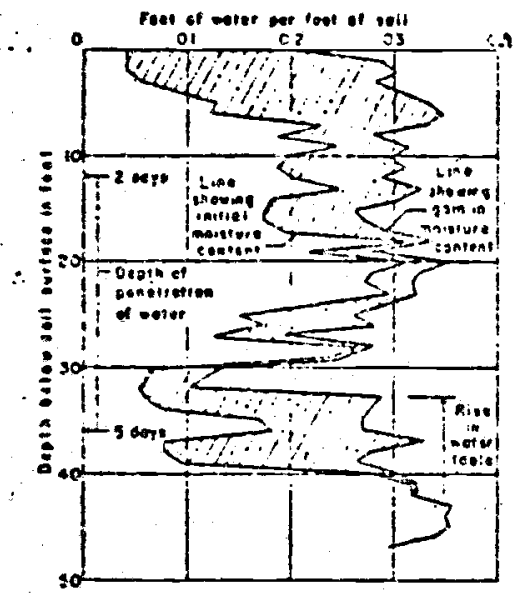

-FIC. O-Change in soil moisture affer sprealine waier for 12 ridys in basin at Irrudville. Calif.

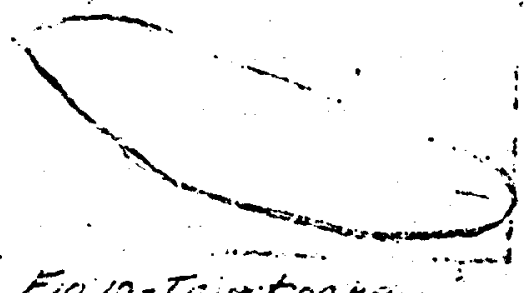

Figpa-Tijatoristouncoveriperineodenirid at a deptroñ ziretists

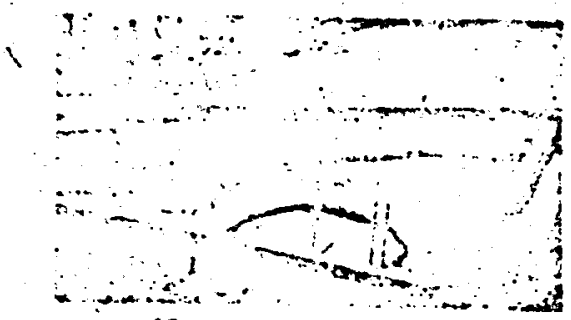

Fisll-Irajectron ra-

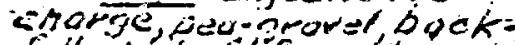

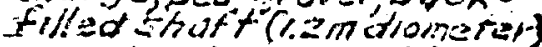
with 15 cmisond fister:
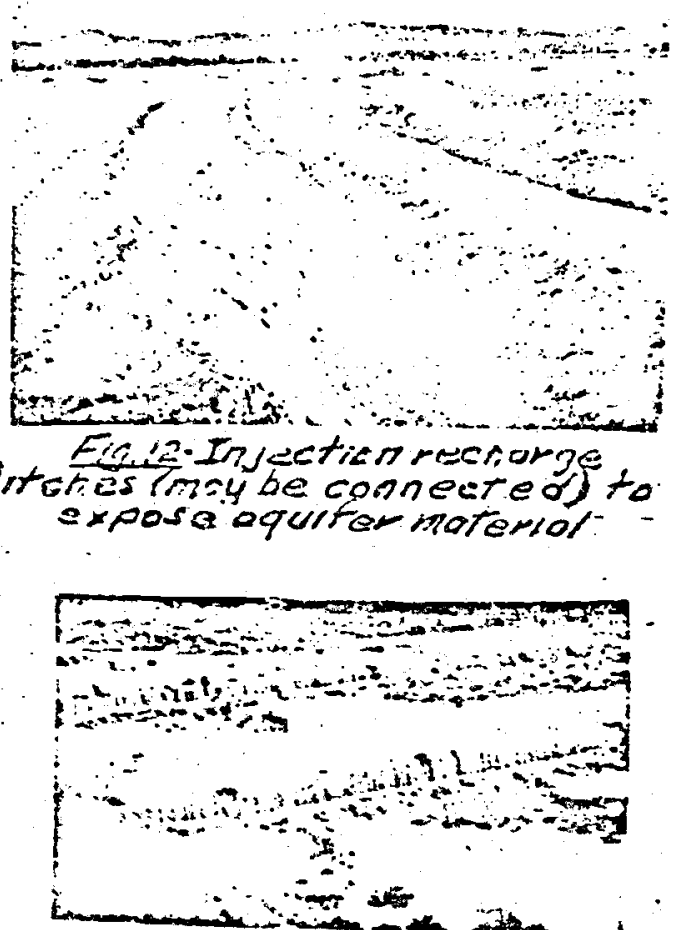

Fing Surtociso: trarge wine-ond-pche smoll.

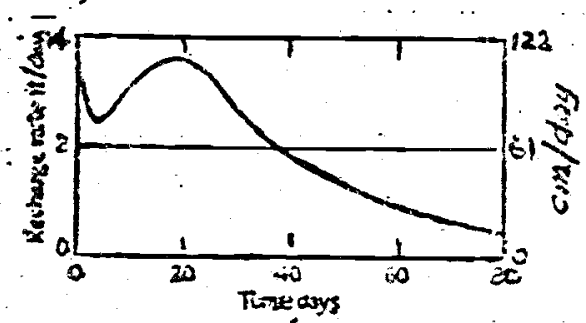

Fiog-Iiffitrotion-

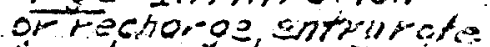

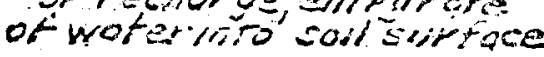


of soll particles and sone movement of soil particles; the recovery is due to the ellmination of entrapped air; the firal decline is die to clogging and microbial activity if a food substance is avallable in the soll for bacterial activity. Drying causes a recovery in infiltration rate, hence the weting of some basins while cthers are being dried for recovery in infiltration rate.

Injection methods such as pits, shafts and trenches may be used where the topsoil, the subsoil and/or upper strata limit infiltration rates into aquifer material. Results from an experimental pit, Figure 10, page 10, wero reported by Schiff, 1356. The sand exposed is two meters below the soll surface. The overall area of the pit is 0.405 hectares and the sind aquifer is 0.014 hectares. Rates up to 17.7 meters per day were achieved, (compared to 1.2 meters for the topsoil) or about 2.48 hectare meters per day. For the technically inclined, computations for velocity and hydraulic conductivity are given in Figure 14, Appendix 1.

Giavel back-filled shafts placed in channels may be used if characteristics so dictate, Schiff, 1956. A square wooden frame with a screen is placed over each shaft. Sand is placed in each frame or box. The sand filters out sediments that would normally go into the shaft. Occasionally when water is not in the channel the deposits on the top of the sand tilter are scraped and removed. Figure 11, page 10, shows an experimental shaft with sand filter. Another approach is to back-fiil the shaft with small gravel to about $15 \mathrm{~cm}$ from the top and then fill to the surface with sand.

Other metheds of recharge include a canal that meanders in permeable soil or a series of ditches, Figure 1\%, page 10. Figure 13, same page, shows small wire-and-rock check dams used in a wide, shallow stream with a permeable bed.

The recharge method or system used will depend on information cittained using approaches described in discussing key Figures 1 and 5.

With the information now avallable to the writer, the grassed, interconnecting, basin method appears to offer the most potential for recharge in Afghanistan. Perhaps pits or shafts bachfilled with sand at the end of each or some of the basins, may be a desirable addition. The method(s) or systems selected depend on the soil and substrata characteristics. Bermuda grass has increased rates in basins from 0.4 to 1.2 meters per day and assimilated "reasonable" sediment loads. Recharge irrigation using alfalfa on basins would provide less recharge, but a food for livestock. Here the combination with pits or shafts at the end of each or some basins may be a good approach to increase recharge. 


\section{Water l'sed for Recharge}

It is usually desirable to avoid spreading water from initial high runoff Lows of rivers or streams as such tlows contain considerable sediment in suspension. ilowever, diversions or pumping (includes floating pumps) from the upper part of the flow avolds bedloads and thus much of the sediment.

Since excess surface runoff, generally of good quality is used for recharge, there is a dilution of salinity of the ground water. This is an important benefit of recharge.

\section{Work by Farmers}

Farmers could do the work rcquired for shallow wells and construction of recharge methods and systems with little supervision after sites and approaches are selected. The Interest of farmers in the use of ground water has been attested to, work suggested herein provides more as surance of success in using ground water.

Ground water is usually a supplementary supply to surface waier in conjunctive use, although in the highly productive San Joaquin Valley of California about $60 \%$ of the irrigation water comes from wells (more and more artilicial recharge is practiced there). There are many locations in the United States where ground water is the main supply of water for irrigation.

\section{Management}

It is necessary that farmers maintain wells and equipment and recharge facilities. Extension service agents and extension workers could provide necessary information. Management is necessary to maintain ground water at "safo eievations" through proper use and recharge. This will minimize the negative effects of years of low surface runoff and droughts (includes training of farmers, technicians, and extension workers). 
Agricultural Development Eank Project, Afghanistan Well Test and Site Report, 1973.

AzImi and McMillan, Report on Ground Water Dovelopment, 1977

Dlagnosis and Improvement of Saline and Aikall Solls, United States

Sali sity Laboratory Staff, Agriculture Handbook No. 60, USDA

1954 (an updated version pending).

Ercon Eagineering and Resources Consultants, Ifydrological Investigaticns

of the Hari Rud Basin bctween Marwit and Ghuryan, Afghanistan,

Phase I and II Reports, January 1973, December 1974.

Jones, R. J., U.S.G.S., Program of Ground Water Resources Investigatlons for the Helmand-Arglandab Valley Authority, Afghanistan, Administrative Repirt, LashkarGar, Afghanistan, December, 1971.

MeClymonds, fi.E., Shallow Ground Water in the Zamin Dawar Area, Helmand Province, Afghanistan, U.S.G.S. for U.S. $\Lambda \mathrm{ID}$, Jan. 1972.

Rendell, A. \& others, Ground Water Reconnalssiance in the Aughandab River Basin near Kandahar.

Sammel, E. A., Ground Water Reconnaissance in the Arghandab River Basin near Kandahar, U.S.G.S. for U.S. AID, December 1971.

Schiff, Leonard, Devices for Measuring Soll-Water movement in Designing Recharge Facilitles, Trans. Amer. Soc. Agr. Engrs., Vol. 7,1964.

Schiff, Leonard, Ground Water Recharge Hydrology, No. 3 Issue Ground Water, Vol, 2, Juls 1964.

Schiff, Leonard, Ground Water Recharge Methods hased on Site Characteristics and on Sediment in Flood Water, International Comm. on Irrigation and Drainage, 5th Congress, R. $Z$.

Schiff, Ieonard, the Darcy Law in the Selection of Water Spreading (Recharge) Systems, Symposia Darcy, Dijon, France, 1964.

Svendser, XL. T., Some Aspects of Irrigatior Technology in Afghanistan, 1977.

United Nations, Survey of Land and Water Rescurces, Afghanistan, Vol. II, Geology, Food and Agriculture Organization, Rome, 1365.

United Nations, Ground Water Investigation, Afghanistan, Vol. 1, Development Programme, Vols. 1 \& 2, New York, 1972. 


\section{ACKNOWLEDGMENTS}

Grateful acknowledgment is made to the several staff members of U.S. AID/Afghanistan for their discussions concerning the work, suggestions, and for their arranging of meetings between Afghans, Aid personnel and consultants of Experience, Inc. This developed a close working relationship amongst all, both professionally and personally, and did much toward making the work a cooperative endeavor.

Dr. Raymong Fort, guiding the program for U.S.AID and consultants, constontly worked to further the team's assignments, and his personal cooperation and friendliness meant much to the team's efforts.

The team was assigned a secretary, Mrs. Virginia Alfsen, who not only handled our work rapidly and efficiently, but was aiways cooperative, courteous and pleasant. We were fortunate in having her with cur team.

In regard to the Afghans, the Ministers and their staffs, and others off and on the AID base, one is left with a good feeling abont their cooperation, friendliness and earnest efforts to help their country and the tearn. They are a wonderful people and one wishes them weil in their endeavors. It has been a pleasure working, with them. 


\section{A RECOMMENDATION}

At one time the writer was Research Leader of an Agriculture Research Service project, U.S. Department of Agriculture, concerned with research both theoretical and applied, in determining the effect of the physical, chemical and biological characteristics of water and soil on water movement in soil and substrata, pirticularly as related to artificial recharge, but also applicabie to irrigation and drainage. Threc men formed.a starting nucleus, a bydrologist (surface and ground water); a soll scientist (physics and chemistry) and a soil microbiologist (microbiology and soil). In time a few other scientists were added. Cooperators were the California State Department of IVater Resources and the University of California at Davis.

Such a starting nucleus (possibly adding an irrigationist) of Afghans to study water and soil resources, and relationships mentioned above is recommended for Afghanistan. It could be a cooperative effort of some of the Ministries. This will produce information on natural resources and irrigation invaluable to increasing agricultural production in Afghanistan. At the start, such an effort could be aided by trained scientists in these iieids from another country. 


\section{IRRIGATED SUB-SECTOR ASSESSMENT}

\section{Annex 1}

Use of Grounó Water and Recharge to Increase Agricultural Production

APPENDIX 1 


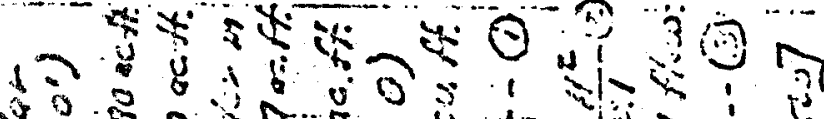

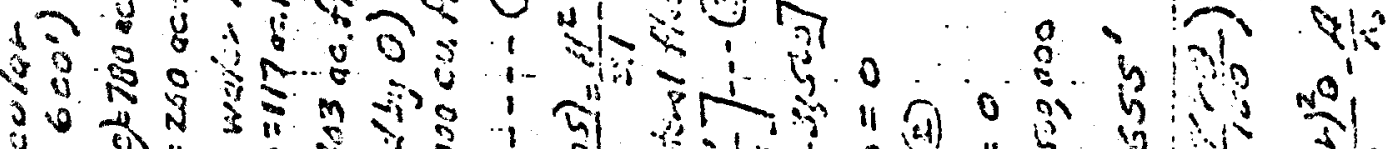

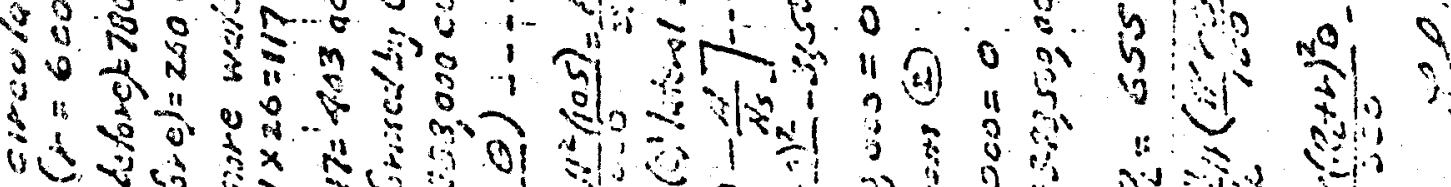

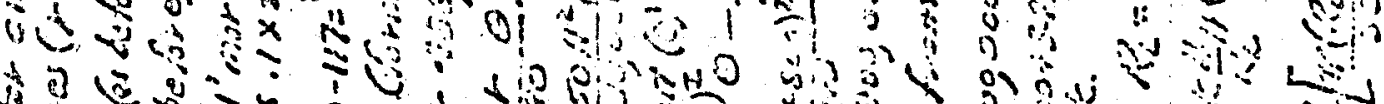

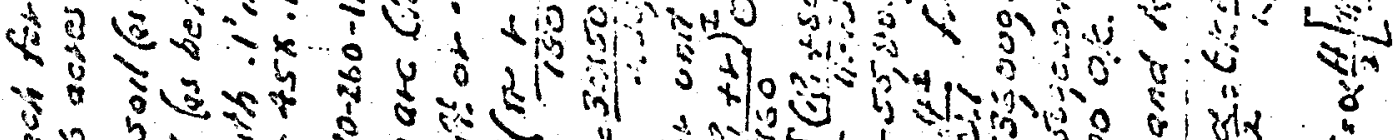

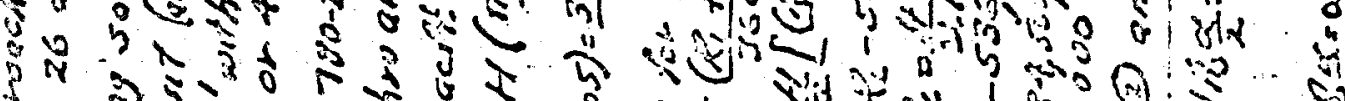

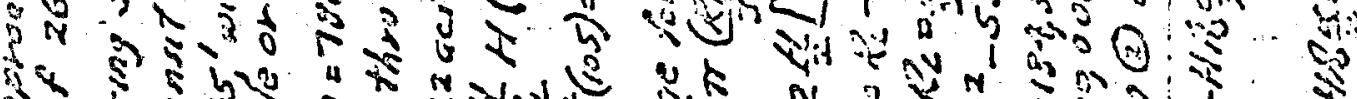

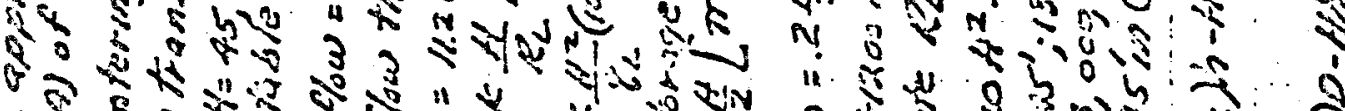

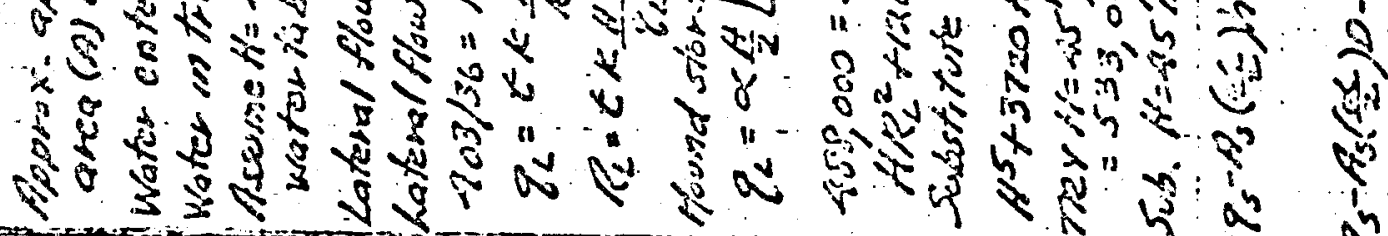

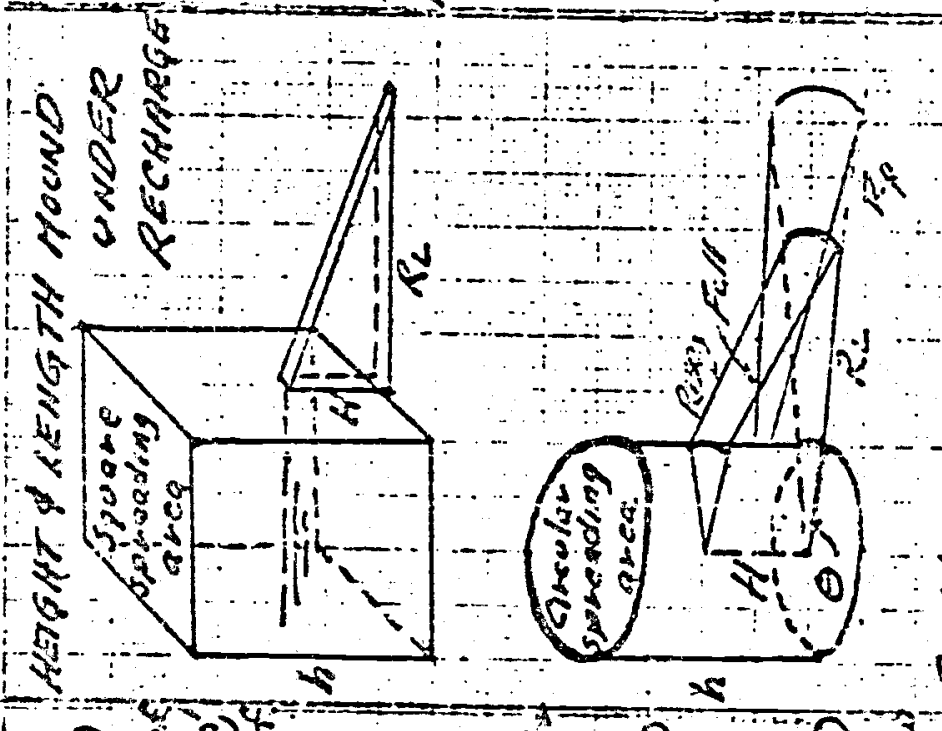

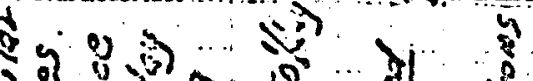

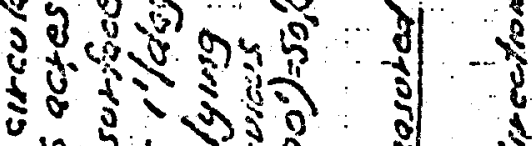

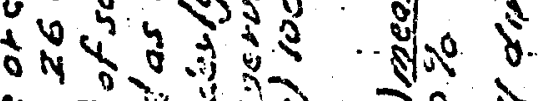

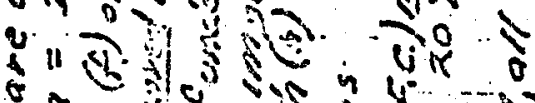

के की

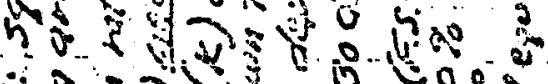

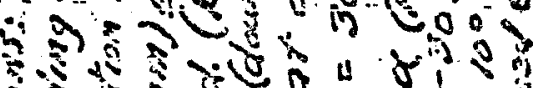
00 a

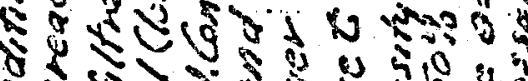

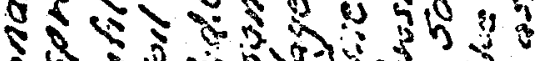

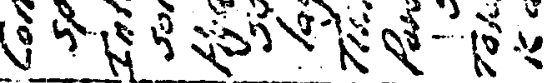

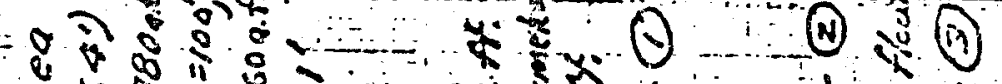

+6 \&

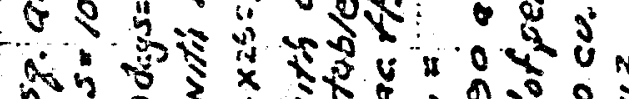

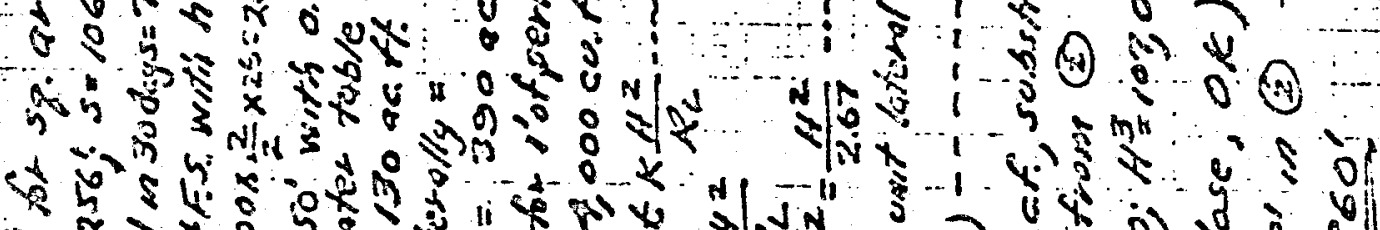

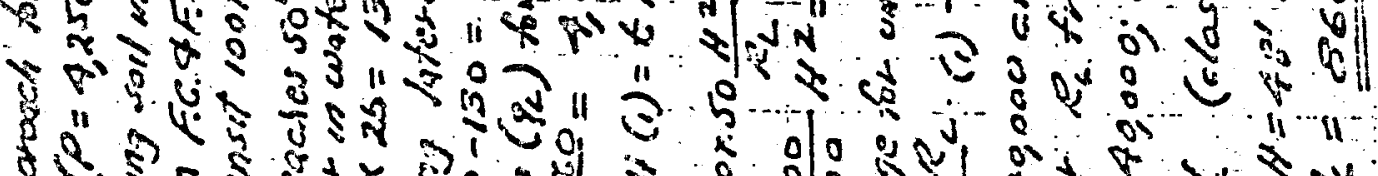

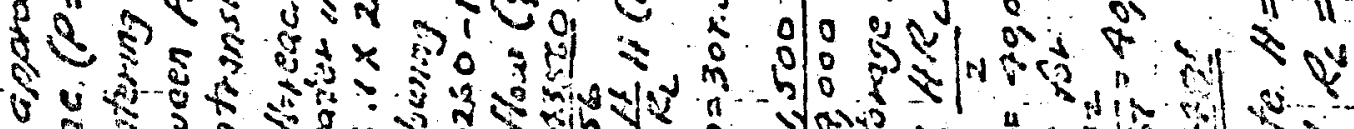

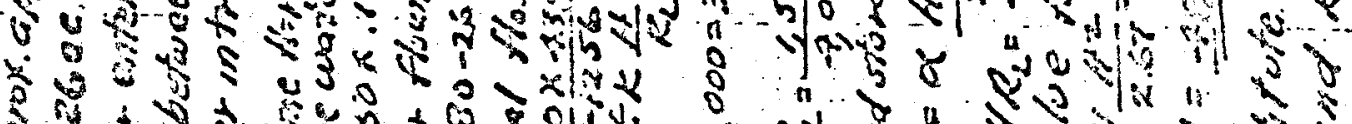

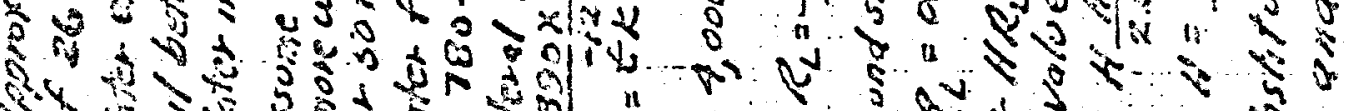

बू. 
Figure 3, Appendix 1

FIGJ-DESIGN OF GRIN DUG WELL SITE

AT

- Solfsurfacez
indintivity

Access
ramp wide)
$(1.0 \mathrm{~m}$ Discharge
pipe

S.W.L. standing water level

Prw.L. Pumping water level

HL dimensions in meters

Not to scale

courtesy GWD Subsection 
The veloxity af how through the su:face of the pit is

$$
V=Q^{\prime} \boldsymbol{u}
$$

"thr: as the area of the pit thrcugh whtch ihe measured rate of How, $Q$, is noving. Using

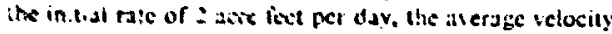

$$
V=\text { Qia }=2.0344=58 \text { feet per day. }
$$

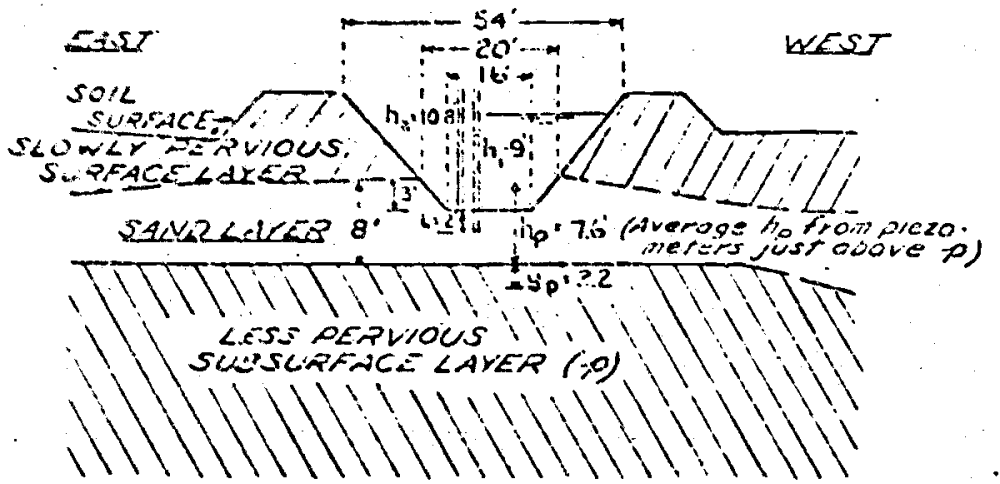

Fie. 7

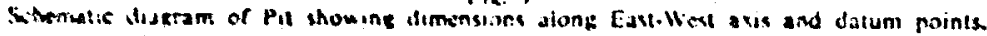

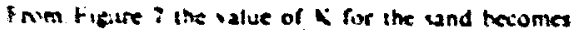

$$
K-\frac{1}{\left(H_{2}-a_{1}\right)} \cdot \frac{s+2)}{(10.8-9.0)}-\text { at } R \text {. per day }
$$

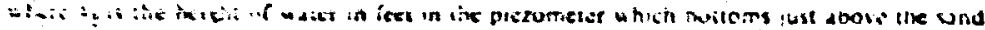

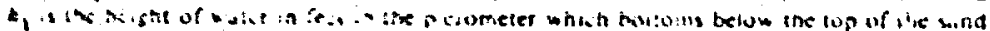

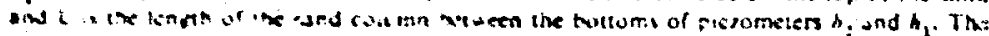

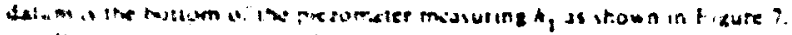

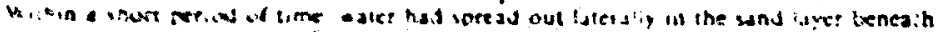

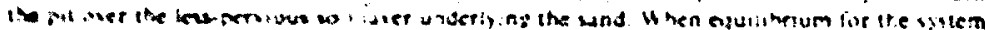

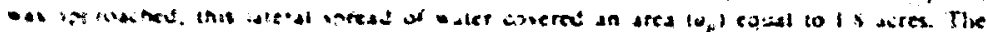

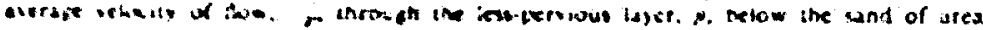
or - 8 eires ata

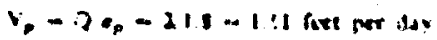

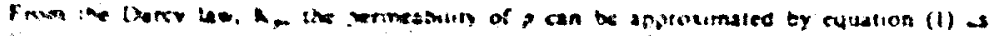
tower

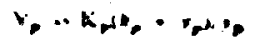

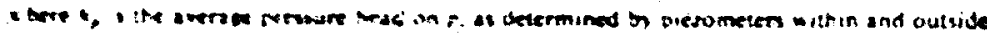

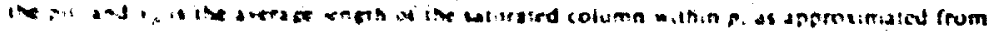

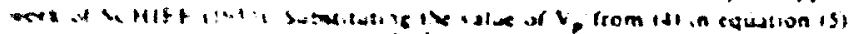

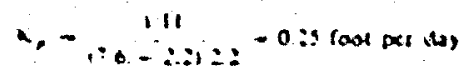

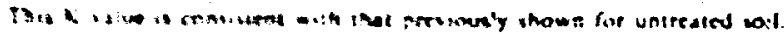

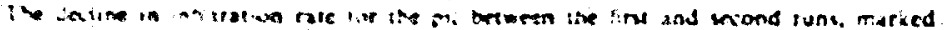

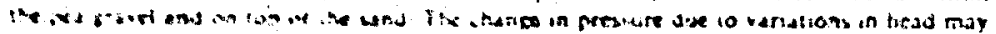

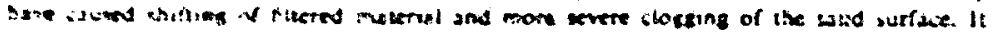
(1)i 

EXPLORATION AND INUENTORY, DEVELOPMENT, AND RECHARGE

BY

\author{
Leonazd Schiff, P.E. \\ Consulting Hydrologist and Agric. Engr.
}

Before discussing ground water technicsl packsges it will be helpful to consider what is happening in Afghanistan. Some atatements made by Afghans follow and are revealing: "there in insuffeient watar lyet runoff is wastod to deserts and. suamps). increase the supply of weter by using more groulid water (particularly shallow wella), inrrease yield of existing karezes and use their waste flows. improve distribution and menagement of watur" Quotes from a faw Afghans from Ministries follow: Mr. Said, Ag Bank, "g number of farmers :want to return their pumps (to Ag Bank) because their walls have gorie dry"; Mr. Asifi, President of tho Ag. Bank indicated at a meeting that more wells are needed but should ba based on a sound development program (it seened he stresses shallow wells, although did not rule out deep wells, largely to help the rural poor): Mr. Azini, President of Planning.. Dept. of Water and Powsr mentions in a report "tha importance of timely ground water development, points to ground weter as often being the most reliable source of irrigation water, aquifars os reservoirs to improve agricultural production and cost savings when compared to surface resorvoirs, ground water supplies must not be neglected he stateg, and zecommsnds ariiijeigi recharqei:; iAstifieial rechargo is not yet practiced in Afghanistan).

The M.I.S. concluced that a potential for grcund wster development"exists and that iarmers are interasted, (but wart moro assurance of success). Dr. Raouf, President water and power Engineering Co. slong with two members of his staff stated that they are developing plais for three areas and are concerned about the possible decline in ground water tables as pumps go in.

Potential Impact of "Technical Packages" in Ground waterm-with the foregoing in mind the tecnnical packages involving ground water may be dividad into three parts, nomely: (1) Exploration and Inventoryi (2) Develonment; and (3) Artificial Racharge. A description of items (1), (2), and (1) rollows: (1) Exoloretion end inventery: Ground water lovels sre declining in a number of farming areas as attested to by the statements given above and the call for artificial recharge. It is now imperative to determine the physical and chemical charectaristics of existing ground water basins that are being used, on a priority basis, stressing areas with sarge number of farmers and rural

If Rcoompanies "Irrigated Sub-sector Agsessment" Annex 1 entitled "Use of Ground Kater and Rechargo to Increase Agricuitural Production by Leonard Schiff, Kahul. Afghanistan December, 19,6 
poos (BC-85 $\$$ of the neopie make their livalihood oft the landi. To ougment information thet now sxiata on logs, profilea and weji testa. portabla, omall-ooro. test. drill sigs ghould bn uaed in etrategic jocetiona. From this information atratigraphic chazmactariaics may be plottec (torturs of sub-atrata, particulariy aquifer macerial. its depth and extant). depth and extent of ground water, quality of ground watar noted, pregent use ralated =o tha amount that can be extracted anfely", and the offect sf graund wets recharge astimatisd luaing surface runoff during
perioda of excose).

Technicel Assistances test hole sites shauld be selected by ground water hydrologist based on existing data and inspection of selected farming axas. Technically-tadined Afghans should accompany thehydrologist as part ci a iraining coursa; commoditjes needea ere containers te collect soil and water samples eignificant changes in substreta, a snoll kit for testing water qualicy. such as solinity and alkalinity, and some sieves. Eguipment includes snall-bora, test, drill rigs. A rig with tow car costs atout $\$ 12,000$ la three-man crew is needed fos each rig, hnwever one rie can cover an appreciable area in a relatively ohort time). financing could come fram credit and/or ceimtursement.

Tho potential impact would be far reaching: proper location of weils. types and optimum depths and spacing of wells. Approximations rould be mode or yields to be expected, effect on water table estimated and arounts of recharge needed.

(2) Develooment: At prosent there are numerous wells, karexas, and springs being used in Afgnanistan that heve additional poteatial for developrent of ground water. The writer also recommends consideration of Infiltration Galleries and ditch interreptors, and has stressed the need for artificial recherge. The potential impact mentioned above applies here. Also karazes waste a great deal of water particulariy during non-ir:igation periods, this water could be used for recnarge in meny arses as a aupply for shallow well(s). Springs may ba developed to yield mare water where conditions warrant. A fiotd trip revealed good posibilities for considering Infiltration Galleries or interceptor ditches. A ground water hydrologist using a soil auger could deterwine potential after ostablihing the gradient (slope of water table) and hydraulic conductivity (ability of soil to transmit ustes). Consideretion could be given to put ing an interceptor acrasfthe head of a karez (at ths botton of the Mother Well) to incrnase flow for additional farming if it is found desirable and foasible in e given location. This would be based on existing data and on minor tests. Technizallv one or two Afghon technicians could work with the hydralogist for training. Egijpment would be small, portable. and inexpensive. Finaneing. although relatively littie would be repuired, could be by credit of reimbursement.

(3) Artifjeial recherce is a must in the writer's opinion, as present netural seepege or unintertional over-irrigation are not arresting the decline of ground water tables in many areas lar the decline that will cosur as more wella go in). Artificial recharge imply means futting excess runotf water underground, now much of it wastes to deserts, swamps or less desiruble places. Recharge 


\section{ANNEX 2}

IRRIGATION SUB-SECTOR ASSESSMENT

The Role of Soils in Land Development

to Increase Agricultural Production

Dr. M.K. Radwan

Soil Scientist Experience Incorporated

Kabul, Afghanistan

Decemiber, 1978 
ANNEX 2

TAPLE OF CONTENTS

I. Introduction

page

II. Soils

3

IiI. Soil Productive Capacity 9

IV. Saline and Alkaline Soils 13

V. Water Quility . 15

VI. Jand Development 18

VII. Soil Capability classification 22

VI.II. Soil Laboratories and Requirements 23 
As a result of technical meetings, review of available data and Eield trips, this Annex, "the kole of Soils in Iand Development to Increase Agricultural Production" was prepared.

Afghanistan depends mainly upon agriculture for its econony: While there is more than one Ministry to deal with water, soils has been left as an "orphan" with very low voice within woth the Ministry of Agriculture and the Ministry of Water and Power. Consequently, little attention has been given to soils since FAO has completed the land survey in 1963. Since then soil activities have been confined to a very few localized surveys for project developinent. The lack of recognition and the understanding of the fertility aspects of the soil in Afghanistan has resulted in the deterioration of the productivity of the land. spread of salinity and alkalinity, and cecrease in fertility due to poor management in all aspects.

Therefore this annex focuses on the role of soils in land development to increase production in Afghanistan, and mentionsat least these main areas in the methodology of this presentation:

- The general description of the soils in Afghanistan - so that their potential in natural resources can be recognized, and their relative quantitative effech can be evaluated in project developmer.t.

- The second main area deals with the management and the fertility aspects of soil to increase agricultural production. The decrease of fertility levels and increase of salinity and alkalinity and fertilization are among the subjects treated in this context:

- The third area deals with the role of soils within the farm infrastructure, and farm practices. Soil-plant-water relationships are also covered.

- The fourth area described is the soil laboratories which are the only tools left to look into that subject. They point out production capabilities of the soil, diagnose the defects and prescribe the remeaial measures. Establishment of a salinity laboratory is consioiered vital. 
- Finally, the report suggests certain corrective nieasures related to each of the above areas and suggests projecta or programs to remedy the situations as solutior interrentions. Research training and extension are also included. 
II. SOILS

A. General physiographic Features

The streams of the country run in long or short narrow or wide valleys separated by hills and ranges. These valley soils are of alluvial, colluvial or mixture origin and are calcareous and non-calcareous. The texture varies from coarse, medium and loamy and have varying depth, a few have heavy texture. In most of the cases the interral and external arainage is good. In general, there is a distinction of three terraces, i.e., terraces, foothill areas and plains. This type of formation leads to different soils. Consequentiy their management should also diffex. Soil properies are different and their suitability for different types of development is likewise different. Many soils show distinct degrees of salinity especially those in the low lying areas.

In all areas, there is a variable portion of the valley land that would benefit by additional irrigation should the water be available. There are also a great many irrigable soils that are badly managed or have deteriorated and in which high water tables and patches of salinity are widespread. It was observed that if soils upstream are added to the irrigated land, the lower reaches of otrer valleys might turn saline or if they are now intensely cultivated they may deteriorate unless proper management and drainage are considered.

In some cases a gravelly layer can be seen in areas right on the foot-hills whereas in other cases gravel forms the valley bottons. Soils with these characteristics are not suitable for irrigation. Possible alternate use as pastures should be considered. There are also areas which show certain limitations which if corrected would put the soils in a higher class of productivity or make them suitable for irrigation.

In other instances where the elevation is nigh and coupled with fairly logical gradient, the valley is physically divided into 2 or 3 soil varieties. The upeer land is cultivable for intensive agriculture, and the middle land is probably cultivable aiso; however, the lower portions will be at the mercy of the intensity of the flow. Consequently the cultivation and production patterns are varied among the three soil identities, and each one also varies with respect to time. 
One encounters soils that are saline to $z$ preventative degree to cultivation, and others in which salinity is somewhat tolerable and yet others in which orly patches near settlements could be cultivated.

Some valleys are characterized by very recent immature soils and in order to irrigate these soils, especially in narr('w portions, infiltration galleries (karez) and wells are used. Erosion has decreased the irrigability of these soils. Their suitability for cultivation is thus limited to low water requirement and salt tolerant crops.

Some saline soils being a part of a tectonic basin have internal irainage. These can be added to agricultural development if an underground water scheme can be launched to irrigate them and reduce their salinity.

Some fans like the Faran fiver alluvial merge into the saline and gravelly desert north of the Helmand Depression. There are indications that cultivation fomerly extended over large areas that are now saline. Better water management and soil reclamation practices are needed to increase the cultivable area.

Some basins can be cultivated with more profitable crops, but are used only for pasture at present, while others can be nore profitable if only restricted to pastures.

In some large valleys, cultivation is found to be confined to its terraces as the surrounding slopes are composed of stony material or outwash fans. Leep valley soils derived from alluvium, colluvium and loess can be very well cultivated. Sometimes the quality of water is the limiting factor unless the soils have good internal drainage. In these cases, if an intensive program of cultivation is adopted, improved drainage and land management programs must be followed.

\section{B. Land Elassification}

Certain wadies or valleys were surveyed in Afghanistan by an FAO reconnaissance team in 1963. The soil classifications were baseci on relevant soil characteristics.including the morphological features of the soil profile, the thickness and texture, the nature of the underlying materials, rate of persolation and water holding cavacity: degree of salinity, erosion, slope and susceptibility to floods.

The following soil classes of the surveyed areas are as given in Tables A2-1 and A2-2: 
I. Very suitable for irrigation

II. Moderately suitable for irrigation

III. Marginally irrigable land

IV. Non-arable, not suitable for irrigation except under special conditions, for irrigated pasture

v. Non-arable, undermined suitability for irrigation

VI. Non-irrigable land.

The above six classes are subdivided to include these subclasses as limitations:

- Limitation due to salinity

- Limitations due to texture, depth, permeability and for inherent fertility

- Topographic limitations such as steepness or irregular slope and erosion

- Wetness, drainage or flooding problems and a high groundwater table.

\section{c. Inventory and Classifying Soils}

In agriculture, water and soils participate in plant growth aild crop production. Water can be identified and measured or approximated in Afghanistan, while soils are not vell described and identified as a natural resource. Soils as a medium for plant growth are the limiting factor for water. usage and crop production.

The quantitative and qualitative chemical and physical Froperties of the soil determine its productive potential. The determination of these properties is required to program nutrient requirements for different plants, orchards and trees with plant feeding material. The lack of these nutrients will cause plant deficiencies, however they can be replenished by fertilizers. The physical properties of the soil play a determined role in water regimes in land use.

The evaluation of the relief, tonography, stratification, texture and structure is essentidi for land and soil utilization before investment in development can be made. They may be limiting or prohibiting factors in the development of the land when it is put under cultivation.

There is a difference between land use and suitability of the land. The land can be used for a given crop, but may probably suit the production of better cash crops, fruit trees or orchards. This has never been deternined in the country. 
properties of the land are needed for hydrology gioundwata: study - roads, constrliction cities, farming, factories. The magnitude and extent of its properties decice its futurd usage. Soil surveys are meant to identify soils of same properties together. Surveys nave different degrees to identify soils of sane properties together. Surveys have different degrees of refining and cetailing. They are reconnaissance as those made by the $\mathrm{FAO}$ in 1963 , semidetalled for project identification and feasibility studies, or detailed for project execution. Specieic surveys are to specific objectives such as reclamation survetc. Taile A2-2

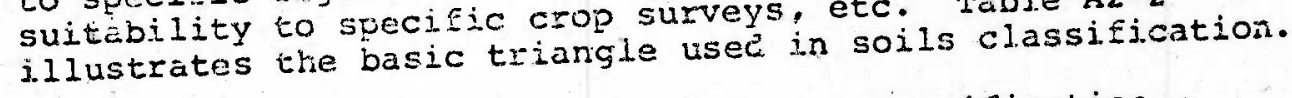

After soil survey cones the capability classification criteria for soil capability classification is aifferent from location to location. Eollowing the capability ciassification is the soil eviluation or value.

In Afqhanistan only a broaa reconnaissance soil survey that is not adequate for judging soil potential is made for certain localities or wadies. It is too general for definite conclusions or agricultural development. As a result, the inventory of the main and only critical conponent in the national wealth of the country has not been detemined. Consequently, any planning is not judged properly. Tho fact that some ccassional localized surveys are made with certain depth does not substitute the need for at least the cabebility soil survey, nor does it cuantify the wealth of the soil as a natural resource.and is a liniting component in aqricultural prosuction in Afqhanistan. If time does not allow the execution of a detailed survey, the least that needs to be done under the circumstances is a short term soil capaijility classification to jetermine with a considerable degree, the most suitable land for agricultural projects and to insure our success in agricuitural development. This quick cepability survey can he carried out in less than a year. It is meant to evaluate the main parameters of potential among the different soil bodies.

D. Some soil physical properties arrd their Determination

The following are three main points related to soil water oroperties:

1. Infiltration rates for the main soils in Afghanistan lie within these categories:

a. Loany textured, ilght mediun soils, reflect good permeability, easily and rapidly absorb the water applied on the surface during irrigation periog. They conserve water if there 
is an adequate supply for the normal growth of the crop.

b. Heavy textured soils which are $10 \%$ in organic matter in the upper horizon, have low permeability. In contrast, light sandy loans or sandy soils will let the moisture move quickly through the soil mass below the root zone into lower horizons. This is one of the main physical points to consider. Examples of this are the soils of the northern parts of Chazn: and Jilga valleys.

The infiltration rate for 5 hours was measured at $.37-.38 \mathrm{~mm} / \mathrm{mincte}$, then falis to .29 and remains steady. Loamy non-saline soi is in this region have more organic matter than many other parts of the country. This can indicate the suitability of chese lands for development. Some higher filtration rates can reach $.45 \mathrm{~mm} / \mathrm{minute}$.

Infiltration rate for salty soils differs from the non-salty scils for the given class texture they belong to.

2. Field capacity of the main:soils are also expected to vary within the country. The heavy textured loams with low organic matter content and non-saline soils will show low rieid capacity.

The field capacity for loamy soils in Afghanistan is in the range of $21-238$ (on dry weight basis). Light textured and non-saline soils have lower field capacity ranging from 16-18\%, while salty soils and fine textures show it generally high. Loamy soils are characterized by higher field capacities 23-328 (due to sait hygros capacity of vaSo4,MgCl2, CaCo2, etc.).

3. Volume weight: $\mathrm{N}_{\mathrm{g}}$ nal soils show volume weight to be $1.34-1.35 \mathrm{gm} / \mathrm{cm}^{3}$. This degree of compactness allows for air and water permeability as well as for a microbial process. If the volume weight values increase with depth the soil will have an unfavorable effect, say if it goes to 1.40 . This results in a recuction of pore space, and cons-quently does not allow the moisture to move properiy through the soil mass. This can result from repeated plowing to the same depth and from irrigation.

Volume weight in the soils of Afghanistan can vary from $1.25-1.6$ or sonetimes $1.7 \mathrm{gm} / \mathrm{cm}^{3}$. This high compaction reflects clay content in the soils and a high mineral content. Volume weight is lower in the salty horizon than in the rest of the prorile. 
volume weight in the soils of Afghanistan can vary from 1.25 - 1.6 or sometimes $1.7 \mathrm{gm} . \mathrm{cm}^{3}$. This high compaction ieflects clay content in the soils and a high mineral content. Volume weight is lower in the solty horizon than in the rest of the profile.

Water storage capacity cu m/hec.:

Farah Rua $0-5 \mathrm{~cm}$. depth

Hari Ruc $(1428-1628)$ $0-100 \mathrm{~cm} . \cdot$ depth $1485-1702$

4. Determination

a. Soil permeability determination to be performed in sites maintaining a constant head of water within two cylinders concentrically placed on the surface of the soil.

b. Field capacity should be determined on a flat ploc of soil. 2n $x$ 2m, apply water at the rate of 2000 cu $m$ per hectare. The plot surface is protected from evaporation - within 2 to 4 days depending on the soil texture, soil samples are taken for moisture determination for successive layers $20 \mathrm{~cm}$. each to a depth of 1 to $1.5 \mathrm{~m}$. made by standard methods

c. Volune weight preferred to be determined on undisturbed soil sample by using a small metal cylinder of $100 \mathrm{~cm}^{\mathrm{j}}$ capacity. 
A. Quality of Soil and water

In most of the lands in Afghanistan the quality of either the soil or the water or sometimes both, is not suoc enough to produce an optimum yield without the sdoption of reclamation measures or special manaçent practices. Salinity and alkalinity are among these unfavorable land characteristics responsible for this requirement. In addition the deterioration of acricultural production on previously productive lands is mainly attributed to the development of salinity and alkalinity.

The lack of awareness of the problems of salt affected soils where conditions permit their formation and of necessary reclamation measures is one of the main factors for the failure of j.rrigations projects; however, early prediction of these hazards helps the timely setting up of land protection programs.

Successful programs must be based on knowledge of the factors involved in the formation and development of salt affected soils and on the adoption of a good methosiology.

These factors are natural and man-made. They are depencent on man to improve or worsen the situation in the land. They are functionally interrelated and thus should be treated in an integzated approach. These are:

\section{Lanc Levelling}

Land levelling is important for efficient water distribution by surface methods. Improper land levelling can creata a inicro relief; variation in depth and homogeneity of soil profile, and pulverization of the fine sandy naterial and changes in the soil structure.

Changes of the micro relief in the order of less than one fcot of soil $(30 \mathrm{~cm}$.$) will resuit in an increase$ of sait content in the raised spots and better leaching in the dips. The spotted salinity patches in poorly levelied soils are a result of thai. With repeated land shaping before crcoping and as the developnent of the land proceeds, the micro relief variation disappears. The changes in depth and homogeneity of the soil profile as a result of land levelling depend on topography, original soil eepth, and nature of stratification and size of earth noving. Where shallow profiles or relatively less permeable layers are exposed clcse to the surface, the chances for develop...ent 
of salt affected sojis bocome mich greater than in trie case of deep and homoqencus soils. Variatisis in soil depth are not easy to correct. There $=0 ;$ improper land levelling operations associated at $\mathrm{h}$ shallow profile tormation should be given more consideration in soil mangerment. Calcareous soi is asa Eine textured profiles (high in silt content) $2=$ affected by land levelling. Pulverization of tha soil naterial, breaking of aggregates and compaction alter the pore size distribution and decrease scil permeability. Such alterations would slow dowa water movement, reduce leaching of salts, encou=sae water logging, and consequently buildup salinityCostly ameliorative measures have to be taken to correct these undesirable effects if improvement of aggregation and permeability cannot be achierad by normal cropping operation practices.

\section{Tillage}

This operation is carried out for numerous rearcms including seed bed preparation and improvement or soji permeability. Tillage can increase salinity th =sugh its relationship with vertical distribution of salts, depth of tillage and scil stratification, soil sasture at time of plowing, tillage machinery and invlesents and timing of tillage.

\section{Planting}

Planting techniques and positions vary with $\leftleftarrows z=$ of crop and can be modified to overcome unfavorabla sonditions for germination and seedling growth. It light be most useful for Afghanistan to follow or test those following practices which indicate a decreasing =-der of harmful effects of salinity on plant stands:

- Plant on top of a single row bed

- Plant near edges of a double row bad

- Plant on side of a sloping bed

- Plant in irrigation furrows

- Broadcasting or arilling of seeds on flat fields followed by heavy irrigation

Soils of high alkalinity and salinity are charact=rized by low permeability and susceptibility to water ssoging. Row crops should be planted on high beds to reci: $=$ the harmful effect of water logging. The amount of sads required for planting a given crop in a salt a $=5 \equiv= \pm$ ed soil is higher than on a normal one. Also, a cectease in the percentage of emerging seedings and a cz:ay' in emergence are to be expected. 
Observations of the ahove rejations would be helpfui in the identification of the advancement of salinity and alkalinity problems. It would be valuable to keep records of the amount of seeds, percentage of emerging seedlings and time of emergence.

Mulching

This practize helps to reduce water lost through evaporation by disxupting capijlary continuity on the soil surface. Generally, the effectiveness of mulching depends on the depth to water table, pore size distribution, climatic conditions and crop cover.

\section{Fallowing}

Under conditions where water is a limiting factor for rop production the land may be left fallow for so:e time; which is done to increase the soil water rese-voir to benefit subsequent crops las in dry farmingl, or until an adequate water supply is available (in irrigated farming). Measures shouid be taken during fallowing to reduce evaporation and consequently, salinization.

The effectiveness of Fallowing depends on other factors including the depth of the water table, quality of groundwater, soil properties, climatic conditions, and length and Erequency of faliowing. Evaporation from a dry surface of fine sandy loan, like many soils in If ghanistan, would proceed at a rate of about 8.3 , if the water table is kept at $90 \mathrm{~cm}$. and $1 \mathrm{~mm} /$ day when at $180 \mathrm{~cm}$. This indicates the importance of the water: table depth factor and the danger of fallowing where a shallow water table exists.

Fallowing should be considered for reducing water 105 by evaporation, reducing salinity, as well as increasing salinity. In the latter case the depth and quality of sround water are the most important parameters.

Application of Manures, Fertilizers, and Amendments

Manure and fertilizer are added to soil to increase its productive capacity. Amendments are applied to correct the harmful effect of the physical and chemical properties
of the soil.

Manuring improves the physical conjition of the soil and enhances leaching of salts and drainage of wet soils. It also has a high mutritional value. In certain soils green manuring is very much recormended. 
Eertilization is an important factor in crop production. The chemical compostion of fertilizers, solubility. rate of reiease and the methods of placement, especially in the early stages of plant growth are factors to be well understood in this connection, especially with regard to incraase of salinity.

\section{Grop Rotations}

Factors governing crop rotation are mainly the availability and adeguacy of soil and water resurces, suitability of the crop to the prevailing climatic conditions and assurance of an economic return. In a reclamation rotation, the suitability of the crop to the soil and water qualities are very important. Inder conditions that encourage salinization, crops should be selected on the basis of their salt tolerance and their effect on the salt balance in the soil. For alkali soils, these should be selected on their tolerance to the sodium ion and to the adverse physical conditions. plants differ also in their water needs in quantity and frequency. Therefore, it is to be expected that salinity of the soil will be affected differently under different crop ratation and vice versa. For example, the salinity will be higher after a rotation of cotton - cotton, than after berseem-cotton-beans, or cotton-berseem-rice. Crops with a long duration of evapotranspiration will cause, in the absence of proper. leaching practices, accumulation of salts in the root zone, while crops such as berseem, rice and others requiring frequent irrigatior. reauce saijinity effectrvely, especially where there is adequate drainage.

Therefore, the knowledger of the salt balance under various crop rotations is very important in order to curb the increase in salinity or alkalinity. Continuous monitoring of salinity and alkalinity after each crop or at least a rotation not only creates avareness of a potential problem but also helps to re-evaluate the management practices associated with the cropping system. Crop performance and yield are good indices of the improvement or ceterioration of the production inputs including soil conditions. 
IV. SALINE AND ALKALINE SOILS

These sequential guidelines are bases for diagnosis and remedial measures in salt affected soils in Afghanistan.

A. Origin and nature of saline and alkaline soils

1. Sources of soluable salts

2. Salinization of soils

3. Alkalinization (accumulation of $\mathrm{ax}-$ changeable sodium in soils)

4. Characteristics of saline and alkaline soils; saline soils; saline aikaline soils.

B. Deternination of the properties of saline and alkaline soils.

1. Sampling

2. Estimation of soluable salts by electrical conductivity

3. Chemical determinations; ph, soluable cations and nions; soluble boron; exchangeable cations, gypsum, alkaline-earth carbonates

4. Physical determinations: infiltration rate; permeability and hydraulic conductivity; density and porosity.

5. Choice of determilations and interpretation of data; equilibrium between soluble and exchangeable cations; factors that modify the effect of cxchangeable sodiun on soils.

C. Soil management in relation to salinity and Alkalinity

1. Irrigation and leaching in relation to salinity control: irrigation; leaching requizement; leaching methods; leaching in the field and trials; special practices for irrigation to prevent increase of salinity.

2. Drainaye of irrigated lands in relation to salinity control: Drainage requiiements; water-transrission properties of solis; boundary conditions; layout and placement of drains; techniques needed for drainage investigations such as measurements of hydraulic head, determination of subscil stratigrapin, determination of water-transmitting properties of soils.

3. Chemical amendments: for replacement of exchangeable soaium: Sulubility of various amenaments unaer different soil conditions; soils containing alkaline-earth carbonates; 
soils containing no alkaline earth carbonates with ph 7.5 or higher and with ph lower than 7.5. Estimation of amounts of various amendments reeded fos exchangeable sodium replacement; speed of reaction of amendments and econcmic considerations; application of amendments.

4. Laboratory and greenhouse tests as aid to diagnosis.

5. Reclamation test in the field.

6. IDENTIFICATICN OE RECIAMATION PROJECTS IN AFGHAN ISTAN

D. Plant response and crop selection. for saline and alkaline soils in Afghanistan

1. Significance of indicator plants for saline soils

2. Crop response on saline soils; salinity and water availabiity; specific ion effects esp. Na, Cl, Bo. bi-carbonates.

3. Crop selection for saline soils: germination; relative salt colerance of crop plants; relative bnron tolerance of crop plants.

E. Quality of Irxigation water

1. Characteristics that determine quality: electrical conductivity; sodium absorption ratio; boron; bicarbonate.

2. Typical waters

3. Classification of irrigation waters: salinity; alkalinity; diagrans for classifying irrigation waters on conductivity and sodium: effect of boron concentration on quality; effect of bicarbonate ion concentration on quality.

4. Additional warer for leaching: It is the extra amount of water that must be appiied and percolate through the active root zone to prevent excessive accinulation of saits. Tt is calculsted through the equation: $L R=\frac{E C W}{E C d w} \times$ ios

where ECW is the electrical Conductivity of irligation water and ECdw is the electrical conductivity $c \bar{I}$ drainage water. IR is the leaching requirements. 
V. WATER NUALITY

A. Introduction

Apart from the quantity of water and its efiect upon the agricultural cevelopment in Afghanistan, the quality of water plays a very decisiv. role. Water quality has an effect upon soils and crops, and on the management that may be necessary to control or compensate for the water quality related problems.

In Afghanistan, downstream water from the different rivers, or that which is pumped out of wells from under the ground is never pure and always contains measurable quanities of soluble salts. In some case's these excessive salts have proven harmfur..

Soils and cropr are affected in different viays by the different kinds of salts in the water. A periodic water analysis is needed to determine what types ,f salts are present. Then these must be evaluated $\therefore$.erms of their expected impact upon the soils and crops.

Water anslysis should include measurements of total soluble salts by means of electrical conductivity, sodium, calcium and magnesium, chloride, sulphate, carbonate and bicarbonates, and other specific constitients such as boran, nitrates, iron and anmonia.

B. Evaluation of Water Quality

The interpretation of the water analysis can be made to cover these problem areas.

1. Total Salinity: This is caused by the totil soluble salts and is measured by electrical conductivity. Total salts have a direct effect upon crops.

2. Permeability effect: This is measured by comparing the relative quantity of the sodium present in the water to the calcium and magnesium. Poor permeability makes it more difficult to supply crops with the water needed for good cropping. It also adds to the waterlogging, salinity, weed and nutrition prcblems. It should be remembered that carbonates and bicarbonates flay a role in permeability status.

3. Toxicity of Specific Iors: Boron, chioride and sodium are the most common ions known to have direct toxic effects on crop growth. 
4. Other Problems: These include the increase of acidity or alkalinity of the water, and vigcrous growth due to excessive nitrogen, etc.

C. Guideline for Quality Interpretation for Irrigation Water

In this guideline, three areas are recognized, no problem, increasing problem and severe problem areas.

SALDNITY

$B C$ of irrigation water $\quad 0.75 \quad 0.75-3.0 \quad 3.0$

PERMEABITITY

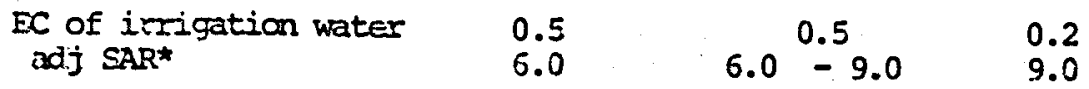

SPBCTTIC ION TOXICITY

Fram Root Absorption

Sxim (2dj SAR)

Chloride meq/L

$\begin{array}{llll}3.0 & 3.0-9.0 & 9.0\end{array}$

$\mathrm{mg} / \mathrm{t}$ or ppm

4.0

$4.0-10.0$

12.0

142

$142-355$

3.55

Boran $\mathrm{mg} / \mathrm{I}$, or: $\mathrm{Fem}$

0.5

$0.5-2.0$

$2.0-10.0$

MISCELILANEOUS

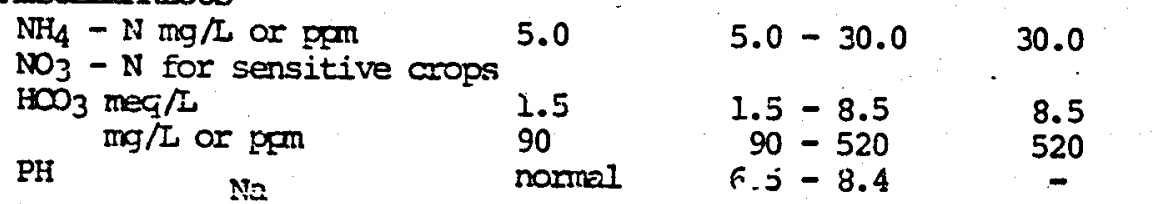

$*_{\text {adj }} \mathrm{SAR}=\frac{\frac{\mathrm{Na}}{\mathrm{Cr}+\mathrm{Mq}}}{2}[I+(8.4 \cdot \mathrm{pHC})]$ analysis should be in meg/L

D. Salinity Protlems

There are two types. The first deals with the salinity of the applied irrigation water and its rapid and direct effect upon crops. The second concerns the salinity that may deveiop in the root zone over a longer period of time due to accumulation of salts, and its effect upon the crop.

The salinity accumulating in the roct zone can be controlled within limits by the application of extra water described as the leaching requirement. However, if the salinity of the applied water is excessive and exceeds the tolerance of the crop, a full potential yield is not to be expected.

Hign water tables complicate salinity problems. Extra water is used for leaching the excessive salts and good drainage is needed to assure that leaching is effective. Changing a crop to another with a higher degree of tolerance may sometimes prove necessary. 
E. Crops Role in Controlling Galinity

Trops have different derrees of tolerance to salts in. wuth water and soils. One of the management aiternatives to reduce salinity is to choose a tolerant crop. A given degree of salinity in water may be detrimental to sensitive crops while it may not be so for semi-sensitive, or tolerant crops.

There are tables available which classify crops and their degrees of tolerance to the soil salinity and water salinity to which they can be exposed. Similar tables are made for vegetable, forage and fruit crops.

Tables $R-1, R-2$ and schenatics $\mathrm{SI}$ and $\mathrm{S} 3$ are relevant in this connection.

F. Additional water for Leaching

It is sometimes necessary to apply more water for leaching in order to control salinity. The mininum amount of this extra water that must percolate through the active root zone to prevent excessive accumulation of salts is known as the leaching requirement (LR). This fraction of water is an extra addition to the water supplied to meet the crop water requirements. Leacling requirement can be calculated from the equation:

$$
\frac{E C W}{E C d ! d} \times 100
$$

Where ECW is the specific salinity of irrigation water and ECdW is the specific salinity of the drainage water at.
the root zone.

Laboratory results of complete leaching of highly saline alkali soils is given in Table R3 as an example.

High water tables can cause a recurrence of salinity at a given soil depth; therefore, deep ones are recommended. 


\section{VI - IAND DEVELOPMENT}

A. Scope and sequence

The need for adequate and reliable information regarding the soils and water resources of each potential irrigation project is an initial step in Iand Development. This requires preliminary soil, watez, and drainage surveys which accumulate the necessary information for long range planning of valley development. Sufficient studies in detail are required as a basis for target estimates.

The basic survey needed usually covers:

1. Soil surveys, reconnaissance or detailed

2. Ground water surveys

3. Drainage studies

4. Hydrologic surveys

Note: Usually detailed surveys follow for the potential projects developed which are from the primary investigation and surveys. For example, detailed soil surveys and soil investigations of certain specific land blocks.

B. The purpose of Surveys and the Reports

These surveys, especialiy soils, water hyarrology, and drainage are presented in maps and tables based on compilation of detailed observations, mezsurerents, and analyses of the land and its associated features; furthemore, they are made and interpreted by the skilied technician in the field for the primary purpose of describing and evaluating the potential use and pioductivity of a parcel of land and the problems inherent with its development and use.

The conclusicns of these broad parameters are to lead to the specific etudies related to the development of blocks of lands which are to be developed following their sequence of priority, as stages of development.

This second stage covers:

1. The relative suitability for present or potential irrigaijon of each soil and soil condition mapped (Land classed as presently j.rrigable; irrigable when put under cultivation or reclaimed; not suitable; or not recommended for irrigation; and the potential low capability classification).

2. The kinds of limitations and relative degrees of intensity of problems to be overcome in developing and using the land salts, alkali, wetness, leveliing, 
eroaibility, flood hazard, soil behavior under irrigation.

3. The best suited crops and sequences of crops for each major group of soils and soil conditions.

4. The crop and soil water requirements (soil properties affecting irrigation) lay out crop use affecting delivery of moisture and nutrients requirements.

5. The relative ecoromics of development and use lestinated development costs, gross and net returns and benefit/cost ratios).

C. Presentation and Reporting

Usually this information is presented in a simmary volume and other specific subject matter volumes and appendices to cover the loge for pits, laboratory data, eic. There might be specific and supplemental reports to cover the use of the working data available to a specific area. These supplemental reports also have appendices to them to cover the specific leqends, soil profile and pit loge, deep or shallow, laboratory analyses, infiltration or leaching trials (ir. case of salinity) and previous preliminary or interim reports. Map follows containing the soils and drainage surveys and interpetation or classification maps for the use in project jevelopment are included. Sometimes the general and supplemental reports are only made for aistribution and the rest are kept for the use by the specialized agency.

D. Iand Development Classification Usually Covers the following features as a minimum:

1. Physiography:

Climate

Native vegetation

Land use and agriculture

Topography and drainage

2. Water Resources:

Surface water sources and their quantities

The hydraulic micro sysiems and the micro systans within each

Quality of waters used for irrigation from the different sources (surface or undercround)

Any relevant data such as degree of efficient use, losses, Eistribution, etc.

3. Soil Resources: 
Soil surveys - degrees, tow they are made, their use and ireseretations Main characteristics of tze land, origin and development of the soils, principal physical and chemical stzacteristics. Main factors affecting ierelopment.

E. Specifin Features and/or treatrez=s relevant to development potential:

1. Land clearing and levell: $=5$

2. Drainage

3. Reclamation treatments

4. Management of different $s=i 1 \mathrm{~s}$ (good, soils reeding special trezinent, etc.)

5. Wind control

6. Erosion, its severity and sontroz.

7. Flood, its severity and csitrol

F. Relative requirements for the devezopment of Land:

1. Crops

2. Water

Requirements for dif_erent crops Plant growtin habits effecting water use Crop rotations and peactices to affect water use

water requirements of srops to be grown in the area

3. Fertilizer requirements

G. Rejative requirements affecting $E=$ ure development of land:

1. Tillage and general farai=s practice

2. Water management, its present use and remedialineasures and aczptation of different soils

H. Potential Agricultural Developmen= and project selection criteria:

1. Estimates of past and present and expected production

2. Summary of presentiy irrigted and potentially irrigable iands.

3. Their costs of developmert

4. Cost/benefit ratio and tis potential of development, development stages, sroduction potential and crop val: $a \equiv$

5. Overall development cost $a-j$ production potentials. 
$\therefore$ Sumary and Recommendations

1. Over all

2. Specific stages and sub-projects 
This project is needec " : the country since this basic information does not ex. with respect to land as a resource identity. It $*$... answer the relative value of the land when either cons. Sered or put under cultivation. It will also clariey the stability of the different lands when put under cti. :ation. No meaningful surface irrigation or undergrour exploration, hydraulogic development without the - serstanding of the soils.aspects. their capability and sideility, can be had..

Requirements :

Tools, equipment, supplins, technical assistance, institutional development, Iancats, laboratory glassware, equipment and chemicals.

The present number of perssnnei is not adequete for an expanded program of sozI : Irvey.

astablishment of a cartorephic unit and photo interpretation unit.

Training abroad for short sourse in soil survey aspects $\because \quad$ and photo interpretation s.a cartography. (Dry desertic and mountainous iocalitiss - institutions) 
VIII. SOLL ZABORATORIES AND REOUIREMENSS

A. Soil Laboracories

Two soil laboratories were visited. One belongs to the Ninistry of Agrict:lture and the other belongs to the Ministry of water ind power. They were once one laboratory, established by FAO in 1960, bi: were later split into two small ineffective ones. The portion that went to the Ministry of Agriculturedeals ith a few analyses and is nore oriented to fertilit: sutermination and plant Eood analyses, while the other tach is left with the Ministry of hater and Power Eeals mainly with such water analyses as soluble salts, acc. Both labs need strengthening with respect to chemicals, glassware and apparatices in order to make a complete soil analysis, tests for water, Eertility, sutrient difficiences or plant feeding tests. The work is paralyzed by the lack of a centrifuge, soil shakers, suction filterina units, hydrcmeters, borsa Eree glassware, salinity meters, chemicals and indicacors. Kjeldahl flasks for nitrogen deteminations are finger counted.

The laboratory personnel have adequate cajatilities for their present activities, but Euture plans sor complete analyses and quality data would necessitate training of the presentstaff and an adequace interpretation of the data has not been done. I=lgation projects are therefore reiient on ampizicoi consumptive use dati and not on injiltration rates, permability of subsurfare, soil texture and soil response to irrigation. U... Jerground water investigation and digging wells are Lune w:. chout any soil anaiyses. The only aboratory effecive idata is the partial analyses related to thr quali-y of water and it total salts.

Neither une of the laboratories is oriente: towar? salinit $=r$ alkalinity problems and its isterpretition. The resulis of any analyses are listed as fejuested on a common shett withoul any intersretation. In this respect a new salinty laboratory is hishy recomnendad. More than hal of the cultivated land has this $\equiv=-s b l e m$ and no governmental division, laboratory, or jersonnel deals with that serious subject at prosen. A highly qualified expert to assist, train and orgasize the perscanei would be of great value.

B. Requirementz

With rispect to the laboratory of the Minist:-y of Agriculture, at least the following should te covered: 
1. The stress has to be oriented to physicochemical aspects of soil properties of Afghanistan with minor localized surveys including the fertility status of the soils.

2.' Proiects related to soil water and soil fertility in relation to crop production:

a. To study the effects of different sources of phosphate fertilizers on through uptake of phosphorous

b. The fixation and release of phosphate in the different soils when applied from different sources

c. The study of the residual effect of fertilization, and the study or the effect of the addition of organic matter on the rate of phosphate release from the soils, and its availability.

d. The study of water nse patterns by crops nut=ient uptake by crops, growth and yield of crops, water and fertilizer uses by crops

e. The study of tillage in relation to crop productivity and the effect of tillage on water storage in soils.

3. Surveys and status of macro nutrients and certain micro nutrients from specific soils and orchards, and the amelioration of the micronutrient deficiency in fruit crops.

4. Soil test crop response correlation studies including the correlation between different soil tests witi: respect to $\mathrm{N} \& \mathrm{P} \& \mathrm{~K}$ and the $\mathrm{yield}$ of the crop and the recommendation of fertilizer rates based on soil tast values.

5. Experiments to establish the most suited crops to the different soils and regions of Afghanistan and the most suitable crop rotation in relation to nutrient requirements and irrigation.

6. A final soil productivity index for different zones should be achieved.

The lab should establish guidelines and give recommendations in soil/water and plant analyses and issue the required certificates. Reports on special forms for all requests should be issued with the qualified interpretations and the suitable recommendations. 


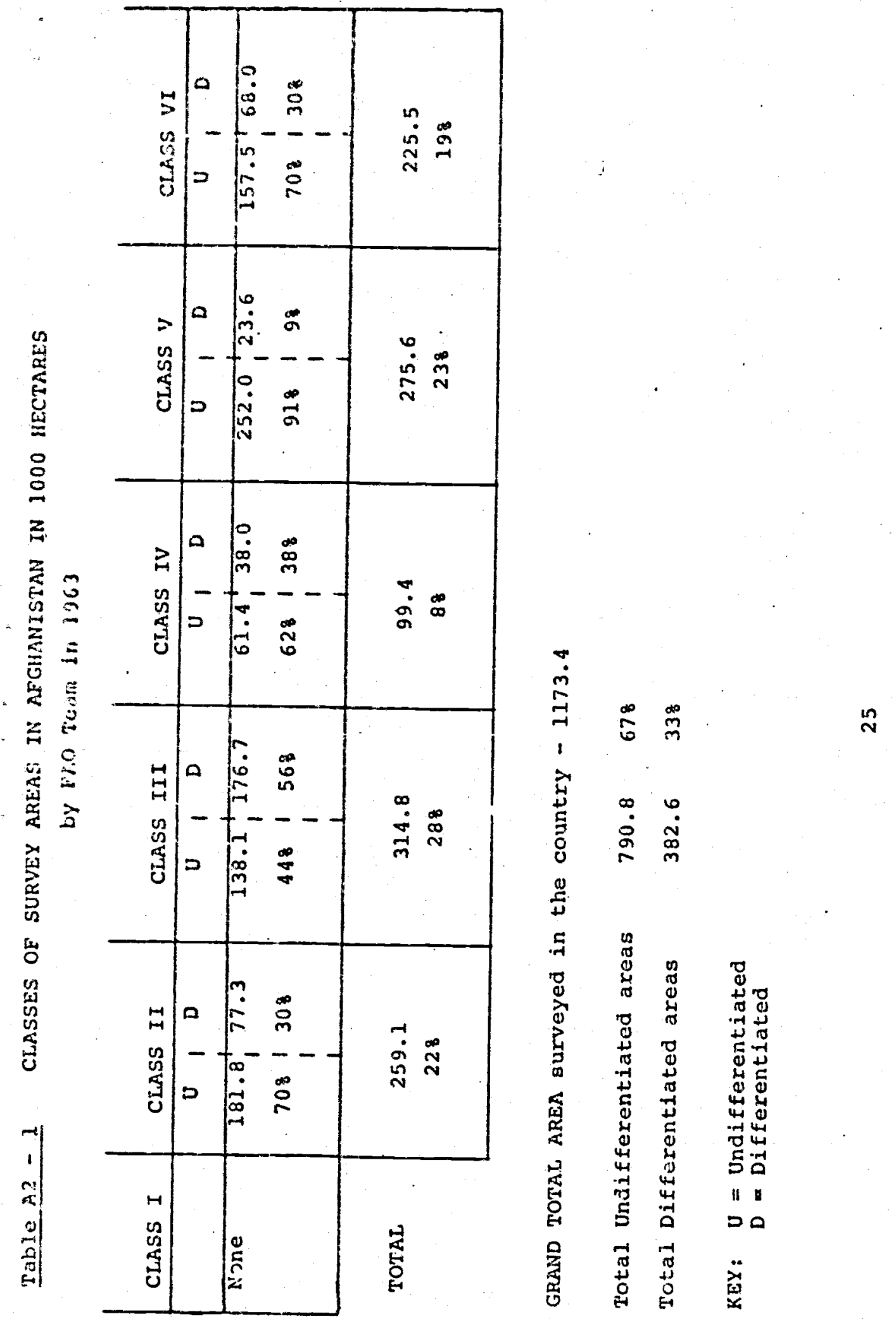




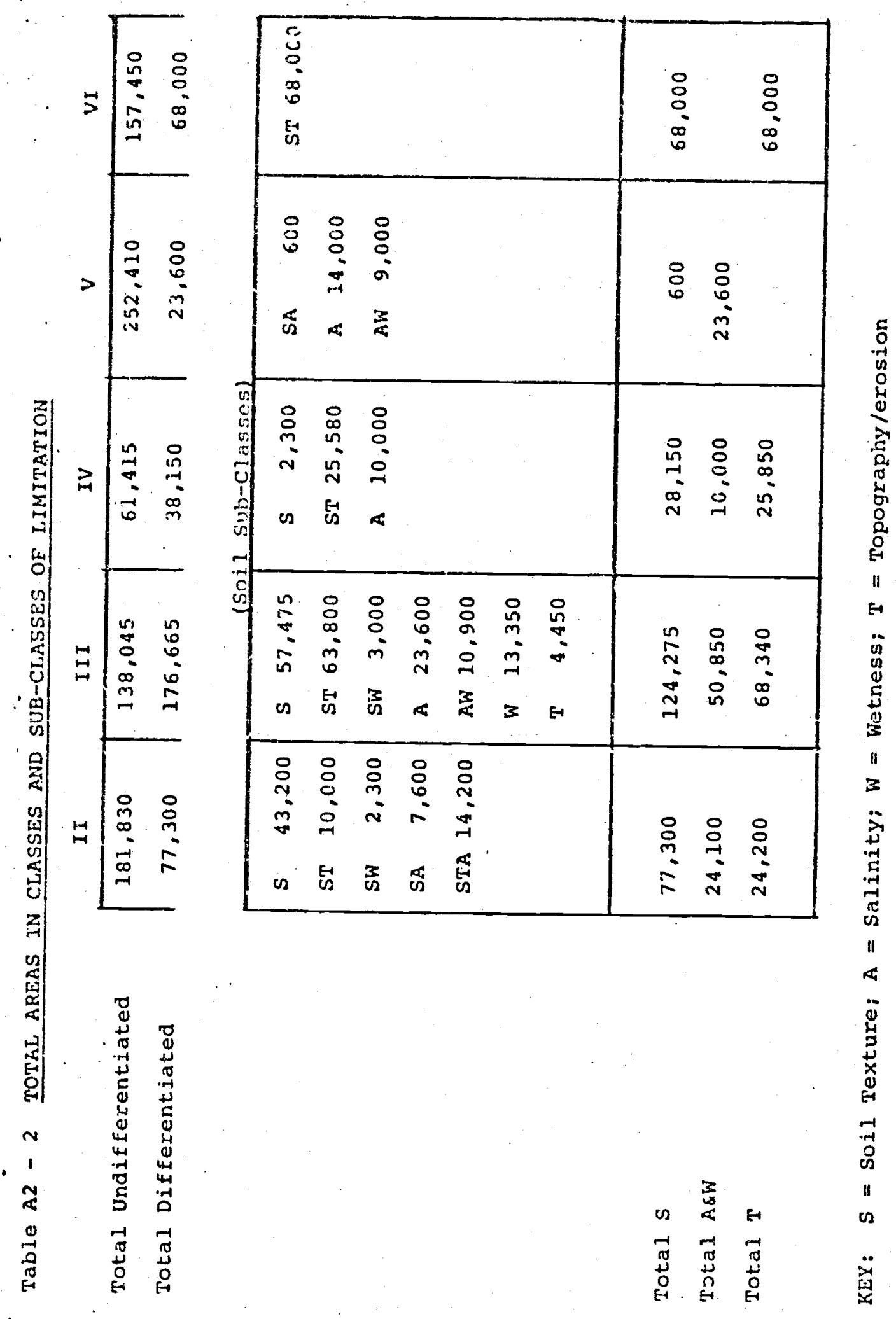



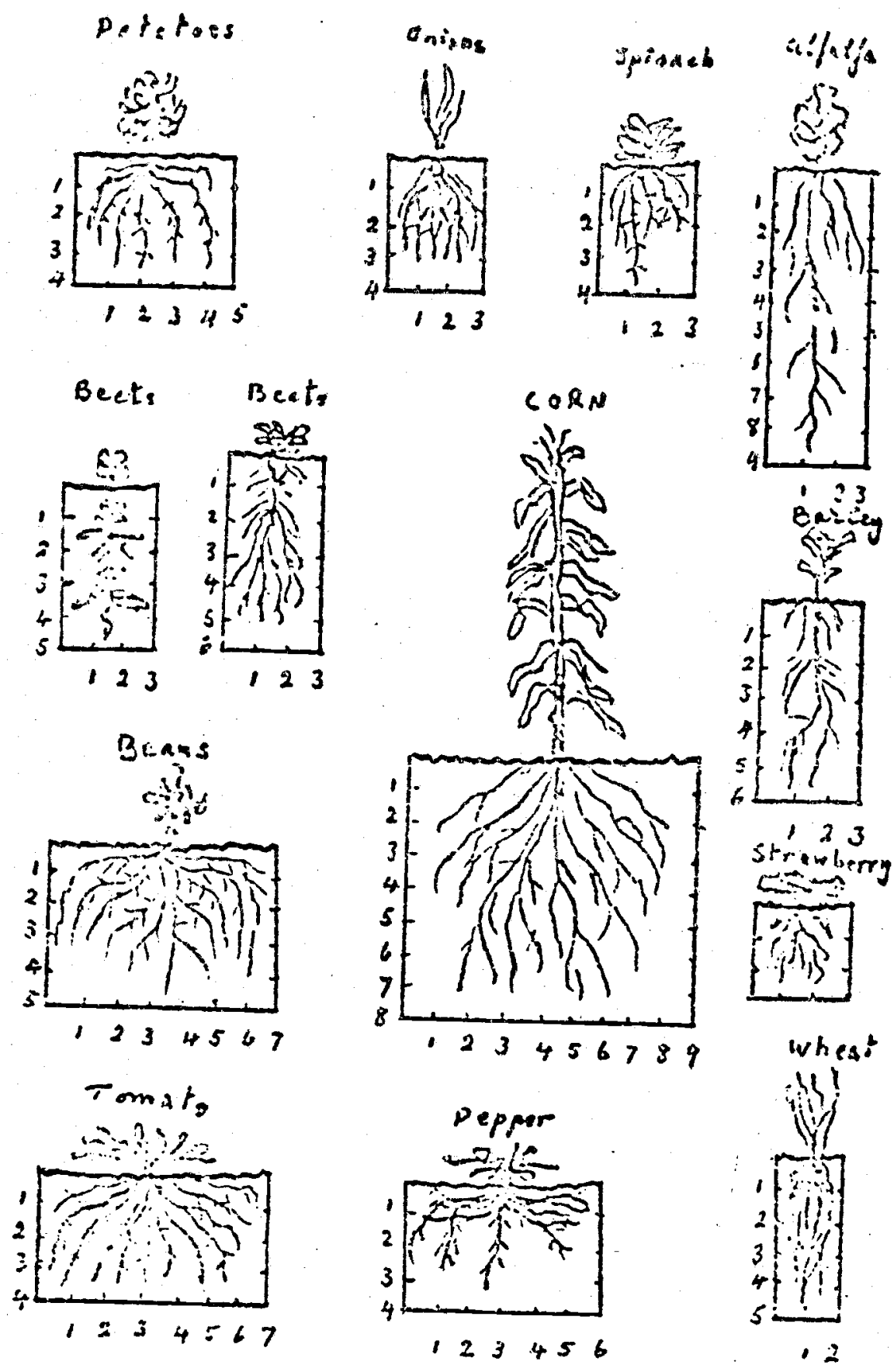

5-l Sanematic Diagram for Root system Distriborition

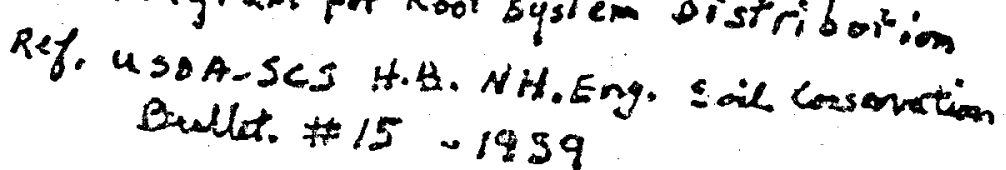




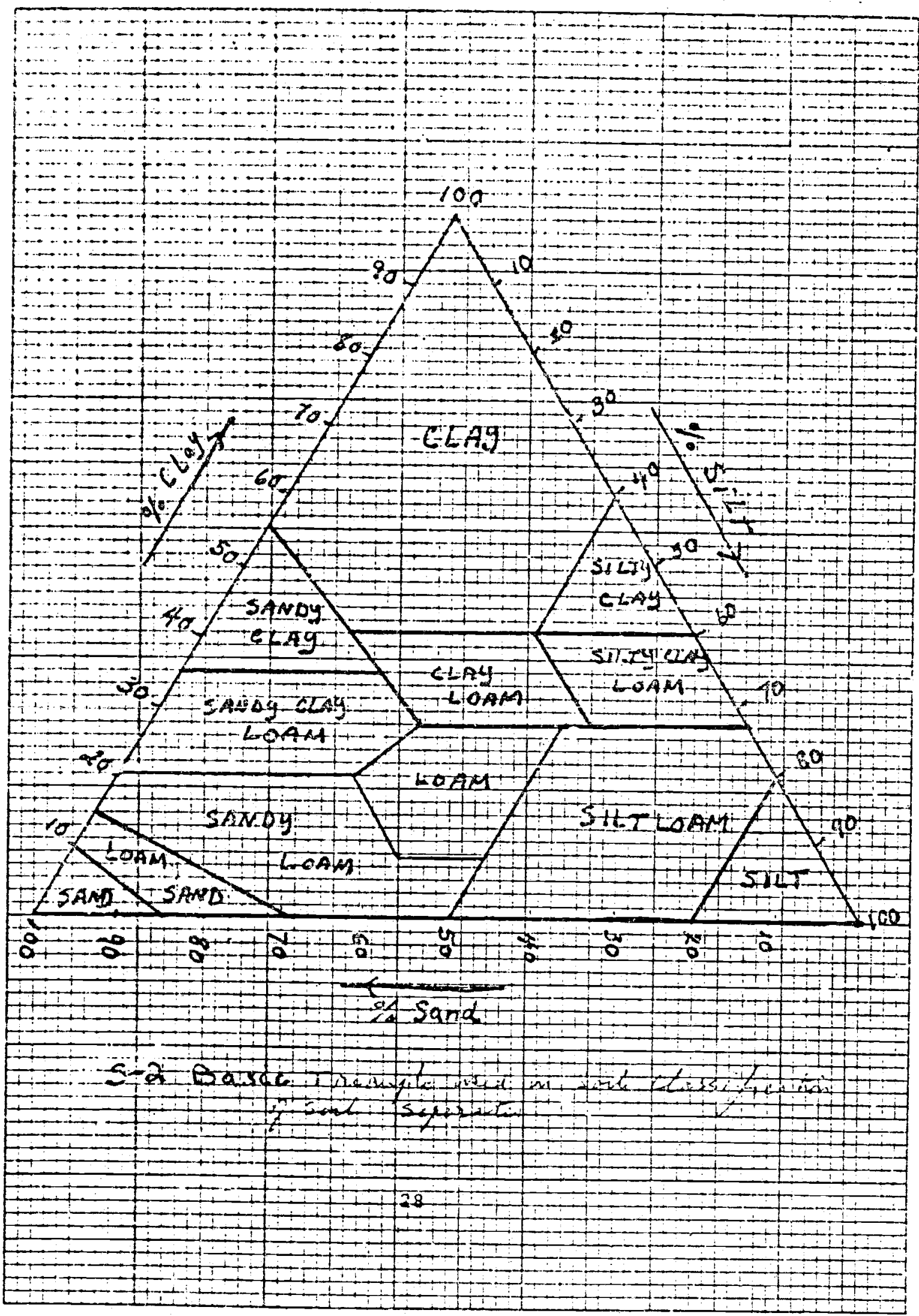




\section{SED AND FURROW IRRIGATION OF SALINE SOILS}

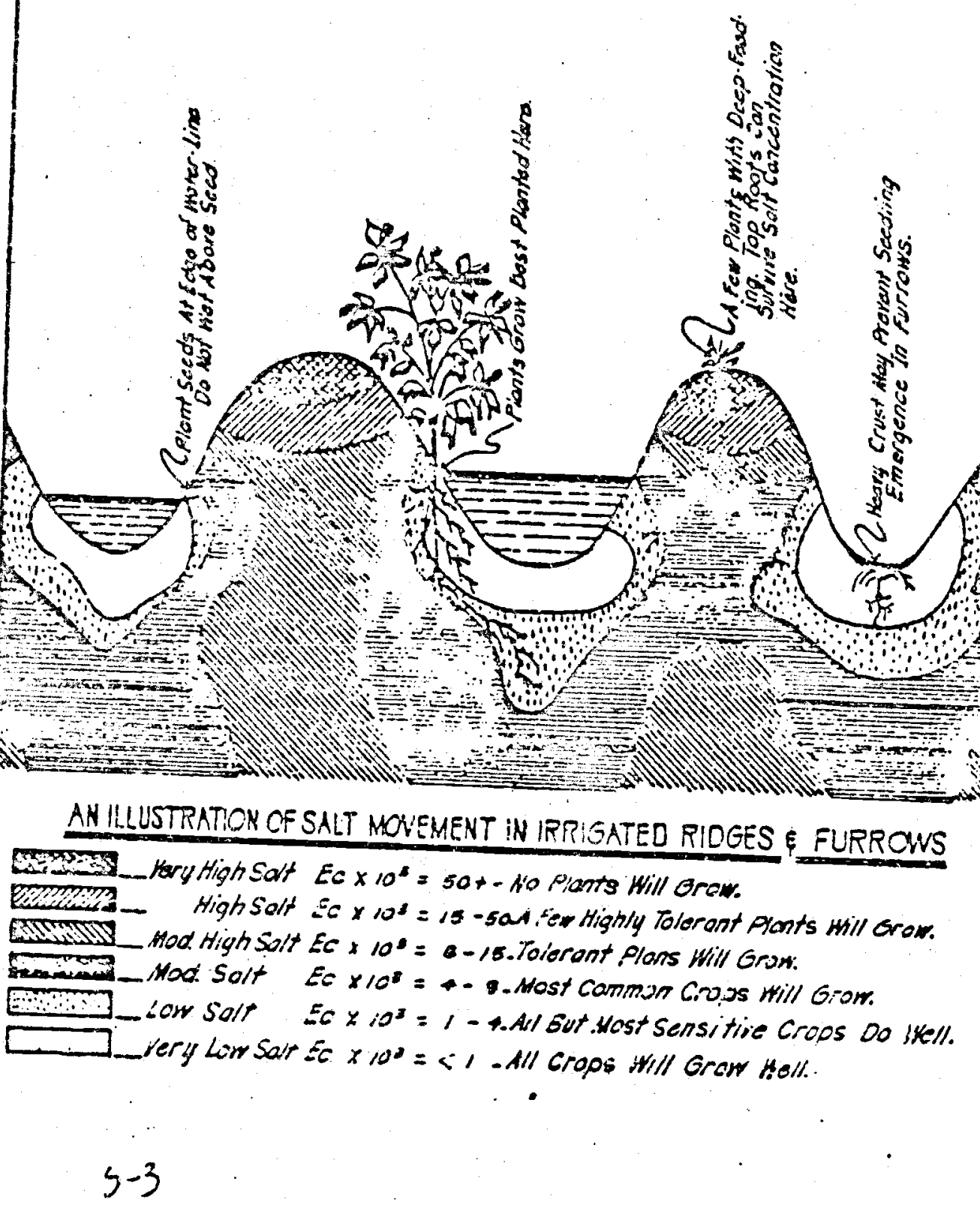




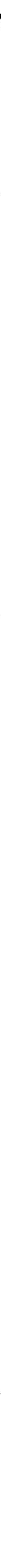




\section{ANNEX 3}

\section{NATIONAL WATER RESOURCES COMMISSION}

The Commission could comprise a Coordinating Board responstble for water policy and water law; its Chatrman would be the Minister of Planning or this designated representative. The members of the Board could be representatives of the Ministries of Agriculture and Water and Porrer; the Rural Dovelopment Department; and the Agricultural Banic. A Mrectorate-General would be responstble for the Implementation of policy, and under him would be thrée Assistant Directorates, esch headed by an Assistant Director as follows:

- Investigations and planaing: This branch vould he responstble for the inventory and classification of surface waters and groundwaters; the investigation of suriace waters through an upgraded byctrometeorological network; and compasable invesígations for groundwater sources, including karezes and springs, through drilling and pumping exploration programs.

Attached to the Investigations and Planning branch would be a National Hydrologic Instftute, which would be an operational organization responsible for kydrologic research, surveys, and data collection, and for making such information readily avaliable 
to agonclos concerned with water development and management.

- Vater Resources Dovelopment: This branch would be responatble for fnvestigating moro offictem meass of developing water rosources and preparing programs for implementation, such as tho artifictal recharge of developed gromdwater rescurces, enlargoment of water intercept areas sich as infitration galleries, or the foasibllity of rumoff irrigation insofar as water resources were concerned.

Conservation and Management: Attached to this branch would bo a Pational Water Resources Ccatrol Agency which would bo responstble for overseeing the apportionment of all water in "declared" groundpater beging, the allocation of surtâo wator supplies, the adjudication of water disputes, the licensing of well drillers and the issuance of permits for well construction, and other conservation and managercert functions as deemed desirable ify the Coordinating Board. 


\section{ANNEX 4. DETAIIS OF METHODOLOGY USED IN REPOHT}

\section{INTRODUCTION}

The methodology ad in this assessment of irrigated agriculture in Afghantstan may do separated into the following five etages, which are deseribed in detall in subsequent paragrapias.

- Data-gathering

- Systein analysis

- Problem identiflcation

- Problem-solving

- Identification of potential programs

\section{Data-gathering}

Tho team reviewed the literature, was briefed by USAID and DRA officiais and outside experts, and then made field trips to selected locations to Afghanistan to study different types of irrigation systems. The objective was to learn as much as possible about the various facets and complexities of all relevant details of irrigated agriculture in Afghanistan.

\section{System analysis}

The system was then separaied into sub-systoms and key variables. The major concern (and the dependent variable for further study) was the 
willization of irrigation water. A supply system and a demsend system, for a representadivo on-farm irrigation system was than developed, each consisting of a number of independent variables- which affected the utllization of irrigation water. Some eleven key variables (six for ths supply system and five for the demand) were idemified, each with mamerous sub-variables. These wore plotted on the diagram shown on Table I-I. Subsequent analysis led to the determination of interrelationships between two or more key variables and other sub-variables - or other key variables. These linkages were sketched in the form of a diagram of interrelated ovals, which is shown on Eable A4.1.

The Joint USAID-Experience, Incorporated Team then met with representaitives of irrigation-reicted DKA ministries to discuss current progress and findings; solicit suggestions and criticisms; and in general obtain a consensus that the Study was procesding correctly. The DRA? partictpation was of assistance - In assigning some prlority to the key variables, e.g. the conclusion that the major problem affecting conveyance systems was seepaze losses.

\section{Problem Identification}

The next step in the methodology was the refinement of probiem identification. Folloping a mumber of discusgions, three discrete problem areas were abstracted from the aforementioned eleven variables, as 
follows:

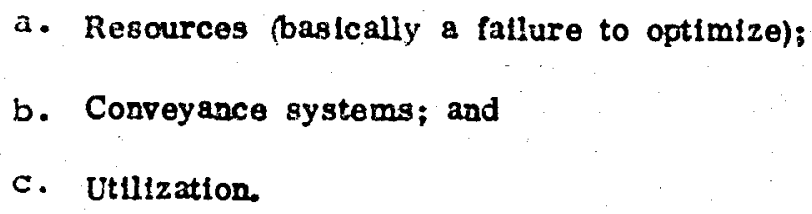

\section{Problem Solving}

The fourth phase of the assessment was the development of possible solutions that would be responsive to the problem areas identifled during the third stage. In subsequent group discussions a mumber of alternattve solutions were proposed to ameliorate or correct these problems. No evaluation of the particular merit3 or feasibility of any particular solution was attempted at that time: the intent was to mtnimize any extended discussion which might have bindered the free flow of Idees. A smaller sub-group then net to discuss the varfous solutions in more detall. At this time, less-reasonable solutions were deleted, related ones were combined, and certain others were elaborated upon and refined. The result of this discrssion was the Problem-Solution Matrix presented in Table A 4.2. This matrix constituted the agenda for the team's second general meeting with DRA officials; at this meeting the solutions developed by the team were presented to the DRA for their comments and criticism. An attempt was also made to assign priority and weight to the solutions offered. While this tactic did not prove ton successful, given the varying 
Interes.ts of the DRA offictals present, the general egreement expressed was that the majority of the soluticins offored by the Teim wero responstve to the Identified problem areas.

\section{Identification of potential programs ("packages")}

In this last stage of the assessment exch possiblo solution was firgt evaluated ugainst several feasibility criteria which reflected USAD project scundness concerns (See Table A-4.3).

However, these criteria were found to be ineffective in fully screening some of these solutions, a situation which might be accounted for as reflecting certain prior (albeit inintentionai) screening to which the solutiong had been subjected in the process of formalation during the group disclisaina sesstons. Indeed, the majority of the solutions were not affected by the feasibility criteria screening.

It aras then decided to proceed to an indexing exercise to identify and label those solution elements which affected

a. The farmer directly through his land; his irrigation supply; his farming practices; and any other activity relevant to onfarm Irrigated agriculture;

b. The common interests of the farmigg community;

c. The nationwide interests of the Crovarnment in supporting the 
ievelopment of irrigated agrieulture; and

$\therefore$ The nnanclal implications with respect to foreseen noeds for technical assistance, tralning, commodittes, equipment, and program funding.

The lndexing exercise culminated in the rocombination of solution allernatives into seven technical packages and ane policy packago. This packagins was then discussed with DRA offictals, churing the course of Whach tholl oplnions were solicited and recelved concerning the nature of the required inputs of technical assistance, comrodities, equ!pment and the types of funding. Their views on the Ninistries and departments who might be involved if any of these packages were to be implemented, were also obtatned. Additionally, the following views were givcn by the DRA ufficials:

1. As most of the pacisages would requite more than oxe agency. for lioplementation, there should be closer coordination and linkage between then. This can be effected through an later-agency protocol.

2. Implementation of systems could be sllocated among interested agencies in accordance with project size as follows:

- Large scale systems: Ministry of Water and Power

- Average or small systems: Rural Development Dept.

- Indiv:dual structures: Farmer bimsalf through credit 
from the Agricultural Bank asd by acquiring the technical skll from the Rural Devalopinont Department.

Agricultural Bank is prepared to tirance technically sound projects ly 'ecelving actvice from the Rural Devalopment Department . and the Mfiulstry of Water and Power.

As Afguanistan is a progressive country, forsiga training would be roqutred for practically all of the paclages.

Demonstration projects would be very useful and should be given important consideration in the relevant packages. 


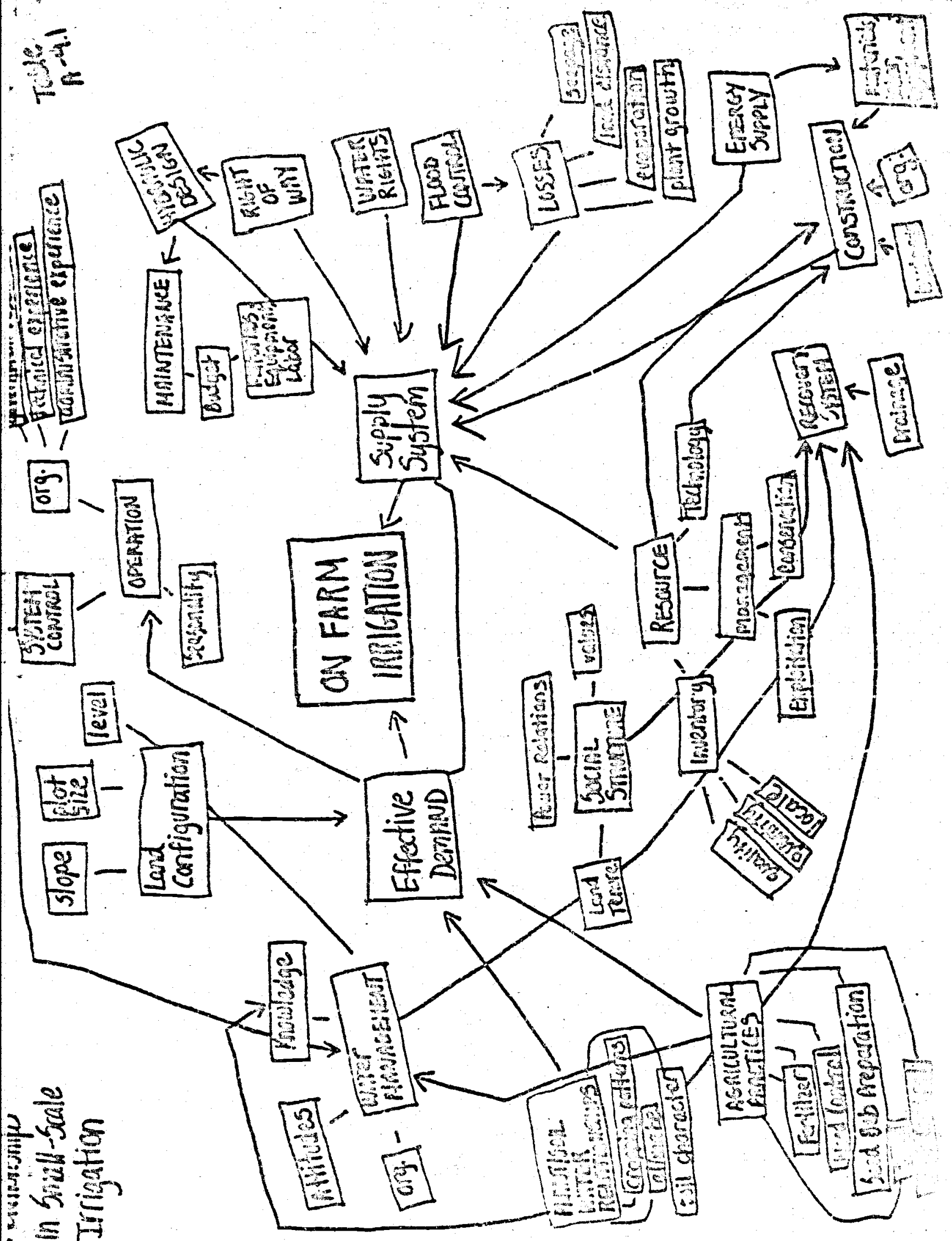


IRRIGATION SUB-SECTOR ASSESSMENT: Alternative SOlutions

Int-axction.

-blems. Problems can be grouped under 3 headings: Problems $=-$ Conveyance System, and Problems regarding the Utilization of - gation water on the Farmer's Field.

- sutions. Solutions to these problems are outlined below. It should $5=$ utions. Before an actual project may be developed, each of -sse alternative solutions will have to be subjected to technicai, a-cnomic, and social anaiysis to determine their feasibility.

\section{PRESER}

1. igsources

1. Lack of knowledge of quantity and quality of resources and how to effectively utilize them.

E. Underground water is an unknown entity; what is now being used is in sine traditional systems of exploitation need upgrading. canger of depletion; and

POSSIBLE ALTERNATIVE SOLUTIONS

1. Inventory and classify solis, surface water, and ground water.

2. Beoin imnediate ground water exploration.

3. Establish Water Resources Comission, responsibie for water policy, water. iaw, aliocation, etc.

1. Begin Underground Water development prograin .

2. Undertake artificial recharge of developed ground water resources.

3. Undertake investigation for further development of karez, particularly on:

a. Storage of wastewater underground

b. Enlargement of water intercept areas.

4. Undertake investigation for furiher development and utilization of springs.

5. Construct Infiltration Galleries.

1. Up-Grade Hydro-Meteorological Networks

C. Surface water Needs to be renitored, conserved, and zugmented if possible.

2. Construct Surface Storage Reservoirs a. on both perennial and non-perennial streams

b. off-stream 
PROSLEM

1. Resources, cont'd.

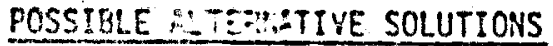

3. Undertake $\geq$ sil and Water Conservation Progra: 2 i=pose control on Resource areis b. Veceestive Practices:

c. Hecranizal Practices

4. Investirate xssibilities of implement* ing a cous-seeding program.

5. Utilize weils to augment surface supply where fass ine.

a. Battery if shallow wells

b. Deep we!l 15
2. Conveyance Systems

A. Current diversion structures need to be improved and other means of capturing water need to be investigated.
1. Up-Grade c:rrent diversion struc ures

a. Make insizenous structures semiperse peit (gabions)

b. Hake in:igerous structures permanent

2. Utilize al zemative lift methods (for example, punts \& motors).

3. Relocate diversions

4. Impose cons-ols on flow of water in karez syetems.

5. Store ka-ez water at exit.

c. Utilize ruti-oif irrigation.

7. Combire diversion structures.

1. Line carais at selective points in the conveyanse systen.

2. Over-des: gri canals to off-set seepages.

3. View seesis: 35 a re-charge to groundwater, $2=\mathrm{s}=\mathrm{ig}$ wells to tap that groundka:er.

4. Shorten lezt canals

a. Desien \& construct more permanent diversi=ns.

b. Puno water from river directly into canal.

5. Improve ria-:enance on irrigation systen:
a. Aquatic =ertrol
b. Weed soraml
c. Silt Rexora! 


\section{PROBLEM}

2. Conveyance Systems, cont: $d$.

C. Flood protection is generally inadequate, and this resuits in major losses in the conveyance system.
POSSIELE H.TEPHATIVE SOLUTIONS

1. Coistruct Headgate control structures.

2. I stail siphons (where irrigation canal gces under wash-crcssings).

3. Construct flumes (where Irrigation canal gcss over a wash-crossing).

4. Build "cut and cover" structures where canal passes across a washcrossing or where it passes along the sides of hills and clifis and is subjected to rock or land slides.

5. Construct diversion channels, guide levaes, or dikes.

6. Build sluiceways.

7. Butress or support canal banks.

D. Physica! structures for controlling water-flow in the conveyance system are lacking or in need of inprovenent.

1. Instali division boxes.
2. Construct checks.

3. Install tumouts.

4. Constrict drop-structures.

5. Incia il metered gate structures.

6. Utilize concrete pipe and close the systen.
E. The social organization of water control and distribution needs improvement.
1. Estabiish a training program for Mirabs and their assistants (chakhbashi)

2. Institute inspection and supervision of mirjb/chakhbashi operations.

3. Establish standards for operation and mainterance of irrigation systems.

4. Fomulate water laws.
3. Utilization.

A. Lack of Knowledge by famer \& technician of efficient water-use practices.
1. Begin research on proper water application rates, based upon local soil/ water/piant relationships.

2. Develcp and disseminate Irrigation Euidelines.

3. Institute on-farm training courses in water manaçent and water-use principles, utilizing: 

$\quad-4-$

PROBLEM

3. Utilization, cont'd.

a. Demonstration plots

b. Class instruction

4. Establish an in-service $t=-T-g$ program for sub-professicretechnicians and especialiy $=$ :ansion
workers.

B. On-Farm Infrastructure related to water-use efficlency is lacking or in need of improvement.

1. Improve on-farm distributice systems, by custring: ....

a. Spiles, siphon tubes

b. Tile channels and drafis

c. Brick/concrete turnouts

2. C. Brick/concrete turnouts - fab turnon: fields.

3. Improve on-farm drainage

4. Dig on-farm wells to augiant water supply during droughts.

C. A soil improvement program related to water-use is urgently needed.

D. Current farming practices are not conducive to effi-. cient water-use. 1. Undertake Land/Soil Improveser. Frogram
a. Increase fertility level s.

i) fertilization

2) scil amendments

b. Reclamation of sni?

c. Sub-soiling
1. Improve Cropping System
a. Crop rotation (including $=\ldots$ sing) ..... 2. Introduce agricultural practi-as which
will result in greater water- $s$ efficiency.

a. Weeding

b. Proper seeding

c. Proper fertilizer applica $=-\pi$

d. " Land preparation

E. Runoff Errigation 
rigation Sub-Sector Assessment:

in: IV Evaluation of Aiternative Technicai Interventicns.

hinliction: The numerous altornative solutions derived mo cur lin.joriling session and subsequently refined in meetincs nim an Fines and in conjunction with our DRA counterparts have wro to he Mliliter. One objective method for doing this is to set Fon a anlier of criteria against which each of the alternative $5: 1 \%$ ans can masured. Those solutions which cannot meet all the cris? are ven a lower priority in the final recumnendation phase, those icll do pass muster against the criteria will likely avsict co fullmingl projects later on:

ySAID project Paper Documentation, each project must bo inis rzed in rm: of its technical, economic/financial, and social scimos. For irurion purpnses for tcday's meeting, we have decided to nith for itilict criteria within that USAID Project Paper Format. $=-$ discussinn. rnurse, we may refine this framework or indeed decide $45 \pi$ ther, nore. invint, criteria. Presented below, then, is a tentative syitionation linima for discussion.

Technical.

Economic/Financial.
1. Institutional capabi to implnimm. the project is avaiti: or or radily develoned thru budine sme technical assistinnce (this ine : anes noth noverrimental and local capasitities).

2. The technical interfor itself is. is technicaliy sound.

3. The solution offered sar tstilize spll $1:$. technolcgy (i.e., icezi: expertize, mill: $i$ l. labor).

4. Local, governmental, int Foreign conllibir: tions can be expecter.

1. Villagers' have cares $=y \Rightarrow$ contribul.. financially to projer:.

2. Benefit-Cost Ratios $\equiv \Xi=$ voralile ( 1 ;

3. DRA willing to comat: personnel to effec: rti: ect success. 
Social.

4. Marketing infrastructure is sufficientiy in-place that increased production, thru irrigation improverent will lead to: increased famer incone.

*. The project will benefit rural, poor.

; The project has the potentfal to spread to other, nori-primary, benefictaries.

z. The project is compatible with the iocal social structue and cultural values,i.e., there wilt be no adverse socio-cultural impact.

I. Viijagers are likely to participate in insian, pian, implementation, and maintenance of project.

Political.

Z DRA willing to make needed polfcy chanms to insure project success.

- Irrigation-related ministries and a!nencin:: willing to cooperate in design, planiiin. and inpiementation of the project.

Z. The proposed project is compatible willi DRA current 5-year flan.

the The project's design package and fundin! ir. acceptable to ORA.

in

Environmental

- No adverse environriental impact is forcoinn. 
- Achisis. One can of course view all of the al ternative solutions as - Jinlly inportant, opting then for a number of different but simultancously

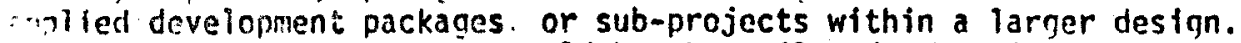
- ir example, one component could be the soll and water inventory, another - zuld be the investigations of further levelopment of springs and karezes;'

: tire same time an immeólate program of groundwater explorition could begin;

is a third package could consist of improvements to CIS structures

fivarsions, conveyance structures, etc.), mirab training, and on-firm $\rightarrow \Rightarrow$ In management training programs (working mainly through demonstrations).

- -h of these conponents could be expanded and sketched in greater detnil. nov are offered here as an alternative to choosing among various but erinally - arabie alternatives. A further advantagg of the component or packagn aroach is that it regroups the variables)into a system, recognizing thint $\therefore:-c$ are dealing with a system and that all the parts are inter-related; tims, te best solution is one which deals effectively with sub-systems with in -tat larger systen. 